Published in final edited form as:

Handb Exp Pharmacol. 2014 ; 221: 137-168. doi:10.1007/978-3-642-41588-3_7.

\title{
The Role of Late $I_{\mathrm{Na}}$ in Development of Cardiac Arrhythmias
}

\author{
Charles Antzelevitch and Vladislav Nesterenko \\ Masonic Medical Research Laboratory, 2150 Bleecker Street, Utica, NY 13501, USA \\ John C. Shryock and Sridharan Rajamani \\ Department of Biology, Cardiovascular Therapeutic Area, Gilead Sciences, Foster City, CA, USA \\ Yejia Song \\ Division of Cardiology, College of Medicine, University of Florida, Gainesville, FL, USA \\ Luiz Belardinelli \\ Department of Biology, Cardiovascular Therapeutic Area, Gilead Sciences, Foster City, CA, USA
}

\begin{abstract}
Late $I_{\mathrm{Na}}$ is an integral part of the sodium current, which persists long after the fast-inactivating component. The magnitude of the late $I_{\mathrm{Na}}$ is relatively small in all species and in all types of cardiomyocytes as compared with the amplitude of the fast sodium current, but it contributes significantly to the shape and duration of the action potential. This late component had been shown to increase in several acquired or congenital conditions, including hypoxia, oxidative stress, and heart failure, or due to mutations in $S C N 5 A$, which encodes the a-subunit of the sodium channel, as well as in channel-interacting proteins, including multiple $\beta$ subunits and anchoring proteins. Patients with enhanced late $I_{\mathrm{Na}}$ exhibit the type-3 long QT syndrome (LQT3) characterized by high propensity for the life-threatening ventricular arrhythmias, such as Torsade de Pointes (TdP), as well as for atrial fibrillation. There are several distinct mechanisms of arrhythmogenesis due to abnormal late $I_{\mathrm{Na}}$, including abnormal automaticity, early and delayed afterdepolarization-induced triggered activity, and dramatic increase of ventricular dispersion of repolarization. Many local anesthetic and antiarrhythmic agents have a higher potency to block late $I_{\mathrm{Na}}$ as compared with fast $I_{\mathrm{Na}}$. Several novel compounds, including ranolazine, GS-458967, and F15845, appear to be the most selective inhibitors of cardiac late $I_{\mathrm{Na}}$ reported to date. Selective inhibition of late $I_{\mathrm{Na}}$ is expected to be an effective strategy for correcting these acquired and congenital channelopathies.
\end{abstract}

\section{Keywords}

Ion channel currents; Electrophysiology; Long QT syndrome; Sudden cardiac death; Cardiac arrhythmias

\footnotetext{
(c) Springer-Verlag Berlin Heidelberg 2014

ca@mmrl.edu.
}

Conflicts of Interest Dr. Antzelevitch is a consultant to Gilead Sciences and Dr. Belardinelli, Shryock, and Rajamani are employed by Gilead Sciences. 
Recent years have witnessed a resurgence of interest in the late component of the sodium current (late $I_{\mathrm{Na}}$ ), particularly its role in development of cardiac arrhythmias and as a pharmacologic target for the prevention of life-threatening arrhythmias and sudden cardiac death. In this review, our principal aim is to discuss the molecular basis for late $I_{\mathrm{Na}}$, its cellular distinctions, and its contribution to the electrophysio-logical function of the heart in health and disease. We refer the readers to recent reviews dealing with the characteristics of the cardiac late $I_{\mathrm{Na}}$ (Belardinelli et al. 2006; Noble and Noble 2006; Saint 2006, 2008; Zaza et al. 2008; Undrovinas and Maltsev 2008a; Maier 2009; Antzelevitch et al. 2011; Shryock et al. 2013) as well as reviews dealing with cardiac sodium channelopathies associated with a gain of function of late $I_{\mathrm{Na}}$ and its role in arrhythmogenesis (Zimmer and Surber 2008; Ruan et al. 2009; Amin et al. 2010; Rook et al. 2012).

\section{Late $I_{\mathrm{Na}}$ and Its Relationship to Peak $I_{\mathrm{Na}}$}

Voltage-gated sodium channels mediate excitability of heart, nerve, endocrine, and skeletal muscle tissues. When membrane depolarization achieves threshold potential, the $\mathrm{Na}^{+}$ channels open, thus giving rise to the "peak" $I_{\mathrm{Na}}$ and the rapid upstroke (phase 0) of the action potential (AP).

The sodium channel activates during phase 0 of the AP and largely inactivates within $1 \mathrm{~ms}$ at body temperature. Between $0.1 \%$ and $1 \%$ the current inactivates more slowly during the plateau of the action potential (AP) (Patlak and Ortiz 1985) with the time constant being between 75 and $450 \mathrm{~ms}$ in humans (Undrovinas et al. 2002; Maltsev and Undrovinas 2006). Amplitude of the late component being small compared with the peak $I_{\mathrm{Na}}$ is large as compared with other ionic currents during AP plateau, e.g., around $0.5 \mathrm{pA} / \mathrm{pF}$ in normal human and canine ventricular myocytes (Maltsev and Undrovinas 2006; Undrovinas et al. 2006). Late $I_{\mathrm{Na}}$ amplitude varies depending on cell type, species, and conditions of measurement (e.g., holding and test potentials, temperature, duration of test pulse, and intracellular $\mathrm{Na}^{+}$concentration). Late $I_{\mathrm{Na}}$ amplitude is reported to be around $0.1 \%$ of peak $I_{\mathrm{Na}}$ in rat (Patlak and Ortiz 1985) and guinea pig (Kiyosue and Arita 1989), but can reach 1 $\%$ in human (Maltsev and Undrovinas 2006) ventricular myocytes. It had been shown that all components of $I_{\mathrm{Na}}$ inactivation are due to different modes of gating of the same cardiac variant ( $\left.\mathrm{Na}_{\mathrm{V}} 1.5\right)$ of the sodium channel (Maltsev et al. 2009).

The amplitude of late $I_{\mathrm{Na}}$ is largest in M cells (Eddlestone et al. 1996) and in Purkinje fibers and much smaller in epicardial or endocardial cells in the canine heart. The more prominent late $I_{\mathrm{Na}}$ contributes to the longer AP and greater rate dependence of AP duration in M cells and Purkinje fibers (Eddlestone et al. 1996; Zygmunt et al. 2001) and thus to transmural dispersion of repolarization. Tetrodotoxin (TTX) is reported to inhibit late $I_{\mathrm{Na}}$ and abbreviate APD more in M cells and Purkinje fibers than in epicardial cells in the dog heart (Zygmunt et al. 2001; Coraboeuf et al. 1979), thus reducing the transmural dispersion of repolarization. In the guinea pig heart, however, late $I_{\mathrm{Na}}$ has been reported to be smaller in mid-myocardial than in epicardial and endocardial cells (Sakmann et al. 2000). The difference appears to be due to methodological considerations. Experiments involving isolated tissues indicate that the guinea pig heart is similar to that of the dog, containing M and transitional cells in the midmyocardium and cells with much briefer APD, showing little 
response to $I_{\mathrm{Kr}}$ block, in the endocardial and epicardial layers (Sicouri et al. 1996). However, unlike the dog, dissociation of myocytes from smaller hearts is fraught with problems because epicardial and endocardial cells are under-represented (Antzelevitch et al. 1999). Indeed, studies involving dissociation of myocytes from guinea pig hearts have reported cells with electrophysiological and pharmacological profiles of $\mathrm{M}$ and transitional cells, but not of endocardial or epicardial cells (Bryant et al. 1998). Rather than lacking M cells, the studies reported by Sakmann et al. (2000) may be lacking in epicardial and endocardial cells.

At the single channel level, late $I_{\mathrm{Na}}$ is predominantly due to sodium channel reopenings during the plateau of the AP (Maltsev and Undrovinas 2006), which allow a relatively small but persistent influx of $\mathrm{Na}^{+}$into the cell. Such activity may be the result of single or bursts of openings of $\mathrm{Na}^{+}$channels (Fig. 1) (Patlak and Ortiz 1985; Undrovinas et al. 2002; Kiyosue and Arita 1989; Liu et al. 1992; Saint et al. 1992; Maltsev et al. 1998). The magnitude of the late $I_{\mathrm{Na}}$ is increased when the channel fails to enter the inactivated state after the initial opening. Sodium channel toxins including aconitine, veratridine, and sea anemone toxin II (ATX-II) prevent the sodium channel transition into the inactivated state, thus increasing late reopening of the channel, measured in excised or cell-attached patches during long voltage-clamp pulses (>200 ms).

\section{Causes of an Enhanced Late $I_{\mathrm{Na}}$}

The magnitude of late $I_{\mathrm{Na}}$ in cardiac myocytes increases in several acquired or congenital conditions such as heart failure (Maltsev et al. 2007; Valdivia et al. 2005), hypoxia (Hammarstrom and Gage 2002), inflammation (Ward et al. 2006), and hyperthyroxinemia (Harris et al. 1991), or due to mutations in SCN5A, which encodes the a-subunit of the sodium channel (Rivolta et al. 2001), as well as in channel-interacting proteins, including multiple $\beta$ subunits and anchoring proteins. Such an increase of late $I_{\mathrm{Na}}$ can be reproduced experimentally by application of natural and synthetic toxins [see (Honerjager 1982) for review] such as ATX-II, veratridine, and aconitine that bind to various sites on the $\mathrm{Na}^{+}$ channel (Denac et al. 2000). It is important to make the distinction between toxins that bind near the local anesthetic binding sites (veratridine and aconitine) and those that bind to the sodium channel at unrelated sites (e.g., ATX-II). It had been shown that these compounds can cause arrhythmias when applied to intact or isolated heart preparations. For example, local application of aconitine causes atrial ectopic activity (Scherf et al. 1948) and ventricular tachycardia and fibrillation (Lu and De 1993). Bursting behavior, which results in a larger late $I_{\mathrm{Na}}$, is reported to be increased as a consequence of some LQT3 mutations including $\triangle \mathrm{KPQ}$ (Hartmann et al. 1994) and Y1795C (Rivolta et al. 2001). Table 1 lists the conditions and agents that are known to increase cardiac late $I_{\mathrm{Na}}$.

\section{Acquired Causes of an Enhanced Late $I_{\mathrm{Na}}$}

Ischemia is the most common pathology associated with enhanced late $I_{\mathrm{Na}}$. An increase in late $I_{\mathrm{Na}}$ during ischemia contributes to the intracellular $\mathrm{Na}^{+}$loading observed in the ischemic heart (Xiao and Allen 1999; Liu et al. 2007; Tang et al. 2012). Simulated-demand ischemia was found to increase oxidative stress, late $I_{\mathrm{Na}}$, and cytosolic $\mathrm{Ca}^{2+}$ levels in rabbit isolated 
myocytes; the rise of intracellular $\mathrm{Ca}^{2+}$ was reduced by inhibitors of late $I_{\mathrm{Na}}$ and $\mathrm{Na}^{+} / \mathrm{Ca}^{2+}$ exchanger (NCX) and by the free radical scavenger Tiron (Zhang et al. 2008). Activity of NCX is markedly increased by reactive oxygen species during re-oxygenation (Eigel et al. 2004). Hydrogen peroxide, nitric oxide, and thrombin are all reported to increase cardiac late $I_{\mathrm{Na}}$ (Ward and Giles 1997; Song et al. 2006; Ahern et al. 2000; Pinet et al. 2008). Nitric oxide (Ahern et al. 2000), hydrogen peroxide (Song et al. 2006), hypoxia (Ju et al. 1996), glycolytic metabolites (Kohlhardt et al. 1989), lysophosphatidylcholine (Undrovinas et al. 1992), and heart failure (Maltsev and Undrovinas 2006) also increase the incidence of bursts of $\mathrm{Na}^{+}$channel late openings that contribute to late $I_{\mathrm{Na}}$. Protein kinases including CaMKII, PKC, AMPK, and PKA are activated during ischemia. Calcium and reactive oxygen species activate CaMKII and PKC (Erickson et al. 2011; Barnett et al. 2007), lysophosphatidylcholine activates PKC and tyrosine kinase (Murray et al. 1997), loss of ATP and elevation of AMP stimulate AMP-activated protein kinase, and norepinephrine release from cardiac nerve terminals leads to activation of PKA and increased L-type $\mathrm{Ca}^{2+}$ current. Each of these kinases, as well as intracellular $\mathrm{Ca}^{2+}$, can modulate $\mathrm{Na}^{+}$channel function or expression.

Late $I_{\mathrm{Na}}$ is increased in myocytes isolated from failing human and dog hearts (Undrovinas and Maltsev 2008a; Undrovinas et al. 2002; Maltsev et al. 1998, 2007; Valdivia et al. 2005; Undrovinas et al. 1999), although peak $I_{\mathrm{Na}}$ is decreased (Undrovinas et al. 2002; Zicha et al. 2004). $I_{\mathrm{Na}}$ inactivates more slowly in cells isolated from failing hearts and the magnitude of late $I_{\mathrm{Na}}$ is 2-5 fold greater (Maltsev et al. 2007; Valdivia et al. 2005). Most Nav 1.5 channels in ventricular myocytes are localized near the intercalated discs where they interact with $\beta I V$-spectrin (Hund et al. 2010) and the rest are in the T-tubules and other areas of the plasma membrane. It is not known whether $\mathrm{Na}^{+}$channels located in these different regions of the cell are differentially regulated in terms of their late current in normal and/or diseased hearts.

The final common pathways leading to an increase of late $I_{\mathrm{Na}}$ in the failing heart, as in ischemia, may be ROS-induced oxidation and $\mathrm{Ca}^{2+}$-induced kinase activation and phosphorylation of the $\mathrm{Na}^{+}$channel and/or channel-interacting proteins (Maltsev et al. 2008; Xie et al. 2009; Gautier et al. 2008). In the hypertrophied and/or failing heart, reduction of repolarizing current contributes to prolongation of AP duration in a nonuniform manner (Keung and Aronson 1981) and to alternans of $\mathrm{Ca}^{2+}$ transients and AP duration (Wilson et al. 2009), thus promoting an arrhythmogenic substrate.

\section{Congenital Causes of Late $I_{\mathrm{Na}}$}

The long QT syndrome type-3 (LQT3) is caused by inherited "gain of function" mutations in the SCN5A gene [for reviews, see (Zimmer and Surber 2008; Ruan et al. 2009; Moreno and Clancy 2012; Blaufox et al. 2012)] and by mutations in $\mathrm{Na}^{+}$channel-interacting proteins that lead to an increase of late $I_{\mathrm{Na}}$ (Abriel 2010). The first description of an inherited LQT3 mutation, a deletion of amino acids 1,505-1,507 ( $\triangle \mathrm{KPQ}$ ) in a patient with a prolonged QT interval, was presented in 1995 (Wang et al. 1995). The mutated SCN5A channel was heterologously expressed in HEK293 cells and demonstrated to cause an increase of late $I_{\mathrm{Na}}$ and of the duration of the action potential (Bennett et al. 1995; Wang et al. 1996). More than 
80 different $S C N 5 A$ mutations that increase cardiac $\left(\mathrm{Na}_{\mathrm{V}} 1.5\right)$ late $I_{\mathrm{Na}}$ have since been described in patients with LQT3. Most LQT3 mutations are missense mutations that cause late current by increasing the probability that the $\mathrm{Na}^{+}$channel will either fail to inactivate quickly or will reopen more readily from the closed state. Some of these mutations occur at sites that are also known targets for phosphorylation by protein kinases (Ahern et al. 2005). Sodium channel mutations such as $\triangle \mathrm{KPQ}$ and $\mathrm{Y} 1795 \mathrm{C}$ cause increased bursting activity of the $\mathrm{Na}^{+}$channel (Chandra et al. 1998; Clancy and Rudy 1999; Clancy et al. 2002) as do mutations in the IFM motif of the inactivation gate (West et al. 1992).

Four $\beta$ subunits have been shown to play a critical role in cell surface expression, subcellular localization, as well as biophysical function of the $\mathrm{Na}^{+}$channels (Abriel 2010; Maier et al. 2004; Meadows and Isom 2005). Mutations in the $\mathrm{Na}^{+}$channel $\beta$ subunits $\mathrm{Na}_{\mathrm{v} \beta}\left(\beta_{1}-\beta_{4}\right)$ are reported to be a cause of congenital LQT syndrome, atrial fibrillation, Brugada syndrome, and conduction slowing [reviewed by Abriel (2010)]. Loss of $\beta_{1}$ expression in mice results in increases of both peak and late $I_{\mathrm{Na}}$ and a prolonged QT interval (Lopez-Santiago et al. 2007). Late $I_{\mathrm{Na}}$ is increased in cells expressing $S C N 5 A$ with the $\beta_{1}$, but not with the $\beta_{2}$, subunit compared to cells expressing SCN5A alone (Maltsev et al. 2009). Mutations in both $\beta_{3}$ and $\beta_{4}$ subunits have been identified in LQT3 and/or sudden infant death syndrome (SIDS) patients and found to cause an increased late $I_{\mathrm{Na}}$ when expressed with $S C N 5 A$ in HEK293 cells (Medeiros-Domingo et al. 2007; Tan et al. 2010).

Numerous proteins are known to interact with the cardiac sodium channel (Rook et al. 2012; Abriel 2010; Vatta et al. 2006; Shao et al. 2009). Mutations in scaffolding and/or cytoskeletal "channel interaction proteins" (ChIPs) are recognized causes of LQT syndrome (Ackerman and Mohler 2010). Mutations in caveolin-3 (Vatta et al. 2006), alpha-1 syntrophin (Ueda et al. 2008; Wu et al. 2008a), and $\beta_{\text {IV }}$ spectrin (Hund et al. 2010; Wu et al. 2008a; Sarhan et al. 2009; Vatta and Faulkner 2006) are associated with increased magnitude of late $I_{\mathrm{Na}}$ and with LQT and/or SIDS. Proteins such as F-actin, telethonin, aactinin-2, and Z-band alternatively spliced PDZ-motif (ZASP) that are anchored at the Zline may participate in the trafficking of ion channels to the T-tubule membrane (Vatta and Faulkner 2006). A mutation in telethonin is reported to increase $\mathrm{Na}^{+}$window current (Mazzone et al. 2008), and a missense mutation in ZASP shifts the voltage dependence of $\mathrm{Na}^{+}$channel activation ( $\mathrm{Li}$ et al. 2010). Reduced interaction of the $\mathrm{Na}^{+}$channel with ChIPs such as the intercalated disc-associated proteins ankyrin-G and SAP97 may lead to a Na ${ }^{+}$ channel loss-of-function phenotype such as conduction slowing or Brugada syndrome (Mohler et al. 2004; Scherer et al. 2008). Silencing of expression of SAP97 reduced peak $I_{\mathrm{Na}}$ in rat cardiomyocytes (Petitprez et al. 2011). The last three residues of the $\mathrm{Na}_{\mathrm{V}} 1.5 \mathrm{C}$ terminus associate with dystrophin protein complexes in the lateral membranes of cardiomyocytes, and a deficiency of dystrophin leads to decreased $\mathrm{Na}_{\mathrm{V}} 1.5$ expression and myocardial $\mathrm{Na}^{+}$current (Petitprez et al. 2011; Gavillet et al. 2006).

\section{Late $I_{\mathrm{Na}}-$ Mediated Arrhythmias}

Patients with LQT3 syndrome are at a high risk not only for Torsade de Pointes (TdP) ventricular arrhythmias but also for atrial fibrillation (Benito et al. 2008; Darbar et al. 2008; Zellerhoff et al. 2009). In studies of isolated hearts and myocytes, enhancement of late $I_{\mathrm{Na}}$ 
using ATX-II, veratridine, or aconitine is reported to cause arrhythmic activity in both atrial and ventricular tissues. In both inherited and acquired sodium channelopathies, late $I_{\mathrm{Na}}$ may be increased while peak $I_{\mathrm{Na}}$ is decreased (Maltsev et al. 2007; Valdivia et al. 2005; Zicha et al. 2004; Makita et al. 2008; Remme et al. 2006) and both can contribute to arrhythmogenesis.

Reduction in repolarization reserve can amplify the effect of an increase in late $I_{\mathrm{Na}}$ to delay repolarization, thus enabling the development of arrhythmias (Wu et al. 2004, 2006, 2008b, 2011)

\section{Mechanisms Underlying Late $I_{\mathrm{Na}}$-Induced Arrhythmogenesis}

\subsection{Late $I_{\mathrm{Na}}$ and Diastolic Depolarization: Abnormal Automaticity}

Spontaneous diastolic depolarization responsible for pacemaking in sinoatrial and compact atrioventricular node cells is driven by ion currents including $\mathrm{L}_{-}$and T-type $\mathrm{Ca}^{2+}$ channel currents, "funny" current (HCN channels), and NCX [for reviews see (Chandler et al. 2009; Hoeker et al. 2009)]. Diastolic depolarization of myocytes in atrial and ventricular tissues is rare in the normal intact heart but is often observed in atrial cells and tissues excised from diseased human (Gelband et al. 1972; Escande et al. 1986; Mary-Rabine et al. 1980; Trautwein et al. 1962) and animal (Chen et al. 2000; Cheung 1981; Hogan and Davis 1968; Wit and Cranefield 1977) hearts.

A critical role for late $I_{\mathrm{Na}}$ in pacemaking was highlighted by recent studies demonstrating that atrial automaticity can be modulated by late $I_{\mathrm{Na}}$ enhancers and inhibitors (Song et al. 2009). Late $I_{\mathrm{Na}}$ was found to be present in atrial myocytes that undergo diastolic depolarization (Song et al. 2009). Sea anemone toxin II (ATX-II), a specific enhancer of late $I_{\mathrm{Na}}$ (Isenberg and Ravens 1984), accelerates diastolic depolarization and induces rapid firing of APs by atrial myocytes (Song et al. 2009). Reactive oxygen species $\mathrm{H}_{2} \mathrm{O}_{2}$ increases late $I_{\mathrm{Na}}$ and causes diastolic depolarization and rapid AP firing of atrial myocytes, which can be suppressed by block of late $I_{\mathrm{Na}}$ using ranolazine $(1-5 \mu \mathrm{mol} / \mathrm{L})$ or TTX $(1 \mu \mathrm{mol} / \mathrm{L})$ (Song et al. 2009). A slowly inactivating TTX-sensitive current, similar to late $I_{\mathrm{Na}}$, was reported to contribute to diastolic depolarization of cardiac Purkinje cells (Carmeliet 1987a; Rota and Vassalle 2003) and of sinoatrial node cells (Baruscotti et al. 2000). In non-pacemaking ventricular myocytes, late $I_{\mathrm{Na}}$ was shown to be present at voltages as negative as $-70 \mathrm{mV}$ (Sakmann et al. 2000; Saint et al. 1992), well within the voltage range at which spontaneous diastolic depolarization can be observed in these cells (Escande et al. 1986; Mary-Rabine et al. 1980; Trautwein et al. 1962). Sicouri et al. (2012a) recently demonstrated an effect of ranolazine to suppress phase 4 depolarization in superior vena cava sleeves isolated from the canine right atria. These findings suggest that enhancement of late $I_{\mathrm{Na}}$ may be a potential cause of atrial arrhythmogenesis.

\subsection{Late $I_{\mathrm{Na}}$-Induced Triggered Activity}

Early and delayed afterdepolarization (EAD and DAD) are important mechanisms of arrhythmic activity whose occurrence is facilitated when late $I_{\mathrm{Na}}$ is enhanced. 
Late $I_{\mathrm{Na}}$ contributes to AP prolongation (Kiyosue and Arita 1989; Liu et al. 1992; Colatsky 1982). Because the magnitude of late $I_{\mathrm{Na}}$ is greater at slow heart rates (Wu et al. 2011; Jia et al. 2011) and the effect of late $I_{\mathrm{Na}}$ to increase AP duration is greater in mid-myocardial than in epi- or endocardial myocytes (Zygmunt et al. 2001; Sicouri et al. 1997a; Antzelevitch and Belardinelli 2006), the role of late $I_{\mathrm{Na}}$ to increase dispersion of repolarization and EAD formation is facilitated by heart rate slowing. A role for late $I_{\mathrm{Na}}$ in EAD formation is supported by findings that enhancers of late $I_{\mathrm{Na}}$ such as ATX-II and anthopleurin-A cause EADs and TdP (Isenberg and Ravens 1984; Ben et al. 2008; Boutjdir and El-Sherif 1991; Song et al. 2004; Ueda et al. 2004; Spencer and Sham 2005; Auerbach et al. 2011). Moreover, inhibitors of late $I_{\mathrm{Na}}$ reduce occurrences of EADs and TdP induced by $I_{\mathrm{Kr}}$ blockers (Abrahamsson et al. 1996; Shimizu and Antzelevitch 1997a; Orth et al. 2006; Wu et al. 2009a), heart failure (Maltsev et al. 2007; Undrovinas et al. 1999), or left ventricular hypertrophy (Guo et al. 2010).

While a modest increase in late $I_{\mathrm{Na}}$ may not cause significant prolongation of AP duration in the normal heart, it can facilitate APD prolongation and EADs induction by $I_{\mathrm{Kr}}$ and $I_{\mathrm{Ks}}$ blockers. Consistent with this observation, individual susceptibility to drug-induced long QT syndromes has been shown to be linked to SCN5A mutations (e.g., L1825P or Y1102) that augment late $I_{\mathrm{Na}}$ (Makita et al. 2002; Splawski et al. 2002). Patients with these $\mathrm{Na}^{+}$channel gene mutations have normal QT intervals prior to exposure to the drugs, but develop long QT intervals and TdP when given agents such as cisapride or amiodarone (Makita et al. 2002; Splawski et al. 2002). Experimental studies involving isolated hearts, tissues, or myocytes have shown that a small increase of late $I_{\mathrm{Na}}$ may facilitate the proarrhythmic effects of $I_{\mathrm{Kr}}$ and $I_{\mathrm{Ks}}$ blockers (Wu et al. 2006; Song et al. 2004), drugs such as cisapride, amiodarone (Wu et al. 2008c), and quinidine (Wu et al. 2008b), as well as "low-risk" drugs such as moxifloxacin and ziprasidone (Wu et al. 2006). As expected, inhibition of late $I_{\mathrm{Na}}$ by ranolazine attenuates the increase of AP duration and EAD induction caused by the combination of ATX-II and $I_{\mathrm{Kr}}$-blocking drugs (Song et al. 2004, 2008). These observations suggest that enhanced late $I_{\mathrm{Na}}$ is a major risk factor predisposing cardiac myocytes to development of EADs under both acquired and inherited long QT conditions.

Delayed afterdepolarizations (DADs) have been recognized as a mechanism of digitalisinduced arrhythmogenesis distinct from diastolic phase 4 depolarization, for over 40 years (Ferrier et al. 1973; Wit and Rosen 1983). DADs are observed under conditions in which myocytes are overloaded with $\mathrm{Ca}^{2+}$, causing spontaneous $\mathrm{Ca}^{2+}$ release from sarcoplasmic reticulum and $\mathrm{Ca}^{2+}$ waves during diastole, leading to aftercontractions (Kass et al. 1978; Kort et al. 1985; Marban et al. 1986; Capogrossi et al. 1987; Stern et al. 1988; Schlotthauer and Bers 2000; Tweedie et al. 2000; Fujiwara et al. 2008). The transient inward current $I_{\mathrm{TI}}$ generated by electrogenic $\mathrm{Na}^{+} / \mathrm{Ca}^{2+}$ exchange is responsible for these DADs (Kass et al. 1978; Schlotthauer and Bers 2000; Fedida et al. 1987).

Enhancement of late $I_{\mathrm{Na}}$, similarly to inhibition of the sodium-potassium pump by cardiac glycosides, causes $\mathrm{Na}^{+}$loading of myocytes. Late $I_{\mathrm{Na}}$-mediated $\mathrm{Na}^{+}$loading reduces the driving force for $\mathrm{Ca}^{2+}$ efflux from the cell via NCX (Noble and Noble 2006; Shattock and Bers 1989), thereby increasing the diastolic $\mathrm{Ca}^{2+}$ concentration and $\mathrm{Ca}^{2+}$ uptake by sarcoplasmic reticulum, and reducing the rate and extent of diastolic relaxation (Fig. 2) 
(Undrovinas et al. 2010; Sossalla et al. 2008). In the normal heart, $\mathrm{Na}^{+}$influx during the AP plateau is estimated to account for $30 \%$ of total $\mathrm{Na}^{+}$influx at a heart rate of $60 / \mathrm{min}$ (Makielski and Farley 2006). $\mathrm{Na}^{+}$influx can be increased several-fold when late $I_{\mathrm{Na}}$ is enhanced by ischemia, lysophosphatidylcholine, $\mathrm{H}_{2} \mathrm{O}_{2}$, or $S C N 5 A$ mutations (Makielski and Farley 2006) thus increasing the incidence of DADs (Song et al. 2008; Wu and Corr 1995). Similarly, in myocytes from failing hearts the late $I_{\mathrm{Na}}$ is increased by $50 \%$ or more (Valdivia et al. 2005; Undrovinas et al. 2010; Undrovinas and Maltsev 2008b).

DADs induced by cardiac glycosides or other interventions are suppressed by inhibitors of late $I_{\mathrm{Na}}$, including TTX, lidocaine, mexiletine, propafenone, R56865, and ranolazine (Song et al. 2008; Rosen and Danilo 1980; Zeiler et al. 1984; Vollmer et al. 1987; Sawanobori et al. 1987; Inomata and Ishihara 1988; Tsuchida and Otomo 1990; Damiano et al. 1991). Reduction of late $I_{\mathrm{Na}}$ by ranolazine and GS-458967, a selective and potent inhibitor of late $I_{\mathrm{Na}}$, has also been shown to reduce the incidence of DADs in experimental studies of pulmonary vein and superior vena cava sleeves (Sicouri et al. 2012a, b, 2013) Blocking late $I_{\mathrm{Na}}$ using R 56865, ranolazine, or TTX has been shown to reduce $\mathrm{Na}^{+}$-dependent $\mathrm{Ca}^{2+}$ loading of cardiac myocytes from normal and failing hearts (Song et al. 2006; Undrovinas et al. 2010; Sossalla et al. 2008; Haigney et al. 1994; Fraser et al. 2006). These findings implicate increased $\mathrm{Na}^{+}$entry into myocytes via $\mathrm{Na}^{+}$channels as a cause of $\mathrm{Na}^{+}$and $\mathrm{Ca}^{2+}$ loading of myocytes, and arrhythmogenic DADs, while inhibition of late $I_{\mathrm{Na}}$ can be used as a means of reducing occurrences of DADs.

\subsection{Role of CaMKII Activation in Augmentation of Late $I_{\mathrm{Na}}$}

Positive feedback loops have been identified between increases in late $I_{\mathrm{Na}}$ and increased expression and activation of CaMKII. These feedback loops appear to contribute to the pathology of $\mathrm{Na}^{+} / \mathrm{Ca}^{2+}$ overload in the failing and/or ischemic heart, where late $I_{\mathrm{Na}}$ (Saint 2006; Maltsev et al. 2007; Valdivia et al. 2005; Ju et al. 1996; Undrovinas et al. 1999; Le Grand et al. 1995) and expression and activity of CaMKII (Kirchhefer et al. 1999; Hoch et al. 1999) are increased. CaMKII phosphorylates phospholamban to increase $\mathrm{Ca}^{2+}$ uptake by sarcoplasmic reticulum (Ji et al. 2003) and RyR2 (Rodriguez et al. 2003) to increase the sensitivity of calcium release channels to $\mathrm{Ca}^{2+}$-induced opening. These two events can lead to increased leak of $\mathrm{Ca}^{2+}$ from the sarcoplasmic reticulum during diastole (Maier et al. 2003; Ai et al. 2005; Guo et al. 2006; Sag et al. 2009; Sossalla et al. 2010; Neef et al. 2010) that may elicit regenerative, spontaneous waves of $\mathrm{Ca}^{2+}$ release causing aftercontractions, transient inward current $\left(I_{\mathrm{Ti}}\right)$, and DADs (Fujiwara et al. 2008; Curran et al. 2010). CaMKII expression and activity is increased in the failing heart (Kirchhefer et al. 1999; Hoch et al. 1999; Ai et al. 2005; Sossalla et al. 2010; Anderson et al. 2011). Inhibition of CaMKII activity was shown to abolish isoproterenol-induced spontaneous $\mathrm{Ca}^{2+}$ waves and DADs in ventricular myocytes isolated from failing rabbit (Curran et al. 2010) and mouse (Sag et al. 2009) hearts, to decrease $I_{\mathrm{Kr}}$-block-induced EADs in rabbit heart (Anderson et al. 1998), and to improve contractile function and reduce the leak of $\mathrm{Ca}^{2+}$ from the sarcoplasmic reticulum in myocytes from failing human hearts (Sossalla et al. 2010). Atrial fibrillation has been associated with increases of both late $I_{\mathrm{Na}}$ and CaMKII activity (Benito et al. 2008; Neef et al. 2010; Hove-Madsen et al. 2004).

Handb Exp Pharmacol. Author manuscript; available in PMC 2015 January 01. 
The positive feedback loop between late $I_{\mathrm{Na}}$ and CaMKII activation is completed by a CaMKII-mediated increase of late $I_{\mathrm{Na}}$ (Maltsev et al. 2008; Wagner et al. 2006, 2011; Aiba et al. 2010; Ma et al. 2012). CaMKII associates with and phosphorylates the $\mathrm{Na}^{+}$channel (Hund et al. 2010; Wagner et al. 2006). Inhibition of CaMKII has been shown to reduce both contractile dysfunction and late $I_{\mathrm{Na}}$ in guinea pig isolated hearts and myocytes exposed to ouabain (Hoyer et al. 2011), and inhibition of late $I_{\mathrm{Na}}$ was shown to reduce arrhythmic activity and a rapid pacing-induced increase of diastolic tension in papillary muscles isolated from mice overexpressing $\mathrm{CaMKIII} \delta_{\mathrm{C}}$ (Sossalla et al. 2011). The late $I_{\mathrm{Na}}$ inhibitor ranolazine decreases phosphorylation of CaMKII, RyR2, and phospholamban in N1325S mouse hearts (Yao et al. 2011). Thus, the feedback loop between the amplitude of late $I_{\mathrm{Na}}$ and CaMKII activity can be interrupted using inhibitors of CaMKII or late $I_{\mathrm{Na}}$, either of which can reduce EADs and DAD incidence, dispersion of repolarization, $\mathrm{Ca}^{2+}$ alternans, and diastolic contracture. Finally, during the development of cardiac hypertrophy and failure, CaMKII appears to have an important role in the regulation of cardiac gene transcription (Zhang et al. 2007; Backs et al. 2009). Sodium channel expression is decreased in the failing heart (Undrovinas et al. 2002; Zicha et al. 2004), but evidence linking transcriptional control of $S C N 5 A$ by CaMKII is lacking.

\subsection{Role of Late $I_{\mathrm{Na}}$ in Dispersion of Repolarization and Related Arrhythmias}

Reentrant arrhythmias generally involve unidirectional block and conduction around a circuit long enough to enable recovery of excitability at each point in the circuit before the circus wave of excitation returns (Mines 1914). The length of the circuit must be greater than the distance that an impulse can travel (i.e., the wavelength, a product of conduction velocity, and refractory period) before reaching the same point again. The establishment of unidirectional block is facilitated by an increase in dispersion of repolarization associated with both acquired or congenital conditions that prolong or abbreviate AP duration and the QT interval, thus promoting the substrate for reentry (Di Diego and Antzelevitch 1993; Antzelevitch 2007, 2008; Patel and Antzelevitch 2008a; Galinier et al. 1998; Yan et al. 2001; Sicouri et al. 2010; Benoist et al. 2012). Computational modeling studies also indicate that increased AP dispersion and weaker cell-to-cell coupling is associated with the susceptibility to reentrant arrhythmic activity (Ghanem et al. 2001; Burnes et al. 2001).

Preferential abbreviation of AP duration and refractoriness in epicardium vs. endocardium under short QT and Brugada syndrome conditions can also provide the substrate for reentry, both in atria and ventricles (Antzelevitch 2008; Sicouri et al. 2010; Antzelevitch and Sicouri 2012; Nof et al. 2010; Fish and Antzelevitch 2008; Patel and Antzelevitch 2008b). Acute ischemia also contributes to induction of reentry by causing electrical heterogeneity and conduction block (Vermeulen et al. 1996; Sidorov et al. 2011).

In normal hearts, late $I_{\mathrm{Na}}$ is greater in Purkinje fibers and M cells than in endo- or epicardial cells, thereby contributing to the longer duration of the AP in these cells (Zygmunt et al. 2001; Coraboeuf et al. 1979) and to spatial dispersion of AP duration and refractoriness. Block of late $I_{\mathrm{Na}}$ reduces AP duration in Purkinje fibers and M cells and is associated with reduction of the transmural dispersion of AP duration. (Sicouri et al. 1997a, b; Shimizu and Antzelevitch 1997b; Antzelevitch and Oliva 2006; Antzelevitch et al. 2006) Augmented late 
$I_{\mathrm{Na}}$ likely contributes to arrhythmogenesis in failing hearts due to increase in dispersion of repolarization and repolarization variability secondary to the increase in late $I_{\mathrm{Na}}$ (Maltsev et al. 2007). Reduction of late $I_{\mathrm{Na}}$ is effective in abbreviating APD and repolarization variability (Undrovinas et al. 2006). Late $I_{\mathrm{Na}}$ enhancers, including anthopleurin-A and veratridine increase the dispersion of AP duration in intact isolated guinea pig and rabbit hearts, respectively (Restivo et al. 2004; Milberg et al. 2005). Augmentation of late $I_{\mathrm{Na}}$ with ATX-II has been shown to dramatically increase transmural dispersion of repolarization and refractoriness in canine left ventricular wedge preparations, giving rise to TdP (Shimizu and Antzelevitch 1997a, b).

Inhibition of late $I_{\mathrm{Na}}$ whether by mexiletine, ranolazine, or other agents reverses the effect of the late $I_{\mathrm{Na}}$ enhancers, effectively reducing spatial dispersion of repolarization and refractoriness, thus suppressing TdP (Wu et al. 2004; Shimizu and Antzelevitch 1997b, 1998, 1999a, b; Wu et al. 2003). Figure 3 illustrates the effect of $I_{\mathrm{Kr}}$ and $I_{\mathrm{Ks}}$ blockers as well as a late $I_{\mathrm{Na}}$ agonist to promote transmural dispersion of repolarization (TDR) and prolonged Tpeak-Tend intervals in the ECG by producing a preferential prolongation of the M cell action potential duration. Block of late $I_{\mathrm{Na}}$ with mexiletine reduces TDR in these experimental models of long QT 1, 2, and 3. Reduction of late $I_{\mathrm{Na}}$ can also reduce spatial dispersion of repolarization and beat-to-beat variability of repolarization caused by treatment of rabbit isolated hearts with the $I_{\mathrm{Kr}}$ blocker, E-4031 (Wu et al. 2009b). Taken together, these results support the view that either reduction of repolarizing $\mathrm{K}^{+}$current or enhancement of late $I_{\mathrm{Na}}$ results in increased dispersion of repolarization that may lead to arrhythmias and that reduction of late $I_{\mathrm{Na}}$ is effective is reversing these proarrhythmic effects (Fig. 4).

\subsection{Role of Late $I_{\mathrm{Na}}$ in Cardiomyopathy}

As discussed above, acquired and congenital defects that augment late $I_{\mathrm{Na}}$ do so by varied molecular mechanisms, including sodium channel phosphorylation, mutations of a specific amino acid residue(s) in the $\alpha$ or $\beta$ subunits, or by alteration of channel-interacting proteins, which may promote varied phenotypes. In addition to congenital and acquired LQTS, an increase in late $I_{\mathrm{Na}}$ can result in mechanical dysfunction of the heart. Dilated cardiomyopathy has been reported in patients (McNair et al. 2004) as well as in mice (Zhang et al. 2011) with mutations in $S C N 5 A$ associated with a gain of function in late $I_{\mathrm{Na}}$. Mechanical dysfunction can result from an increase of intracellular $\mathrm{Na}^{+}$to decrease the electrochemical gradient for $\mathrm{Ca}^{2+}$ extrusion by $\mathrm{Na}^{+}-\mathrm{Ca}^{2+}$ exchange (Belardinelli et al. 2006; Noble and Noble 2006; Sossalla et al. 2008). Slowing of $\mathrm{Ca}^{2+}$ extrusion could lead to slowing of diastolic relaxation. It is noteworthy that patients expressing the LQT3- $\Delta \mathrm{KPQ}$ mutant $\mathrm{Na}^{+}$channel are reported to have an impaired diastolic left ventricular relaxation and AP prolongation that were improved after administration of ranolazine (Moss et al. 2008).

Hypertrophic cardiomyopathy (HCM) is the most common monogenic cardiac disorder encountered in the clinic. Recent studies have identified the presence of cells with $\mathrm{M}$ cell characteristics in the septum of the human heart, (Barajas-Martinez et al. 2013; Coppini et al. 2013) as has previously been described in the canine heart (Glass et al. 2007; Sicouri et al. 1994) displaying higher levels of late $I_{\mathrm{Na}}$. An ameliorative effect of ranolazine was 
shown to reduce the augmented late $I_{\mathrm{Na}}$ and thus to reduce the prolonged APD in the setting of HCM.

Coppini et al. (2013) showed that in cardiomyocytes isolated from HCM, enhanced CaMKII activity slows ICa inactivation and increases late $I_{\mathrm{Na}}$, thus contributing to APD prolongation and related arrhythmias. Their data also suggested that by altering the function of ECcoupling proteins, CaMKII might also contribute to the altered $\mathrm{Ca}^{2+}$-transient kinetics and elevation of diastolic $\left[\mathrm{Ca}^{2+}\right] \mathrm{i}$, which are responsible for the development of delayed afterdepolarizations (DAD). Therapeutic concentrations of ranolazine partially reversed the HCM-related cellular abnormalities via inhibition of late $I_{\mathrm{Na}}$, with negligible effects in myocytes isolated from control hearts.

\section{Drugs That Inhibit Cardiac Late $I_{\mathrm{Na}}$}

Local anesthetic and antiarrhythmic agents, including mexiletine, lidocaine, ranolazine, amiodarone, propranolol, verapamil, pentobarbital, quinidine, and flecainide, as well as antiepileptic drugs such as phenytoin and riluzole, are known to inhibit late $I_{\mathrm{Na}}$ in cardiac myocytes. These drugs lack selectivity for inhibition of late $I_{\mathrm{Na}}$ relative to other currents or receptor targets (Table 2). TTX is a selective $\mathrm{Na}^{+}$channel blocker (Narahashi 2008) that inhibits late $I_{\mathrm{Na}}$ in the heart at concentrations 5-10-fold lower than it inhibits peak $I_{\mathrm{Na}}$ (Carmeliet 1987a; Wu et al. 2009a; Le Grand et al. 1995; Josephson and Sperelakis 1989) and it is commonly used in experiments to validate the effects of other late $I_{\mathrm{Na}}$ blockers. However, TTX blocks neuronal $\mathrm{Na}^{+}$channels at much lower concentrations than those at which cardiac $\mathrm{Na}_{\mathrm{V}} 1.5$ channels are blocked, accounting for its high toxicity.

The antianginal drug ranolazine (Antzelevitch et al. 2011), GS-458967 (Belardinelli et al. 2013), and the Pierre Fabre experimental compound F15845 (Vacher et al. 2009) appear to be the most selective inhibitors of cardiac late $I_{\mathrm{Na}}$ reported to date. Ranolazine has been demonstrated to be safe (Morrow 2007) in patients with non-ST-elevation acute coronary syndromes and angina pectoris. Ranolazine inhibits late $I_{\mathrm{Na}}$ and $I_{\mathrm{Kr}}$ with potencies of 6 and 12-14 $\mu \mathrm{mol} / \mathrm{L}$, respectively, (Antzelevitch et al. 2004) and slightly prolongs the QT interval in humans (Chaitman 2006). It also blocks both $\alpha$ - and $\beta$-adrenergic receptors with low potency (Zhao et al. 2011).

Most drugs that selectively inhibit cardiac late $I_{\mathrm{Na}}$ are believed to bind to the local anesthetic site in the $\mathrm{Na}_{\mathrm{v}} 1.5 \mathrm{Na}^{+}$channel vestibule, and they cause both useand voltage-dependent block of the $\mathrm{Na}^{+}$current (Zygmunt et al. 2011; Nesterenko et al. 2011). Local anesthetic binding to the $\mathrm{Na}^{+}$channel is state dependent, and high-affinity binding depends on the availability of a channel conformation in which certain amino acids are arranged in a specific 3D relationship to form a binding domain (Lipkind and Fozzard 2005). In any different conformation (e.g., the closed state), the same amino acids are present but in different relative 3D positions that do not form a local anesthetic binding site of high affinity. The amino acids that form the putative local anesthetic site in open/inactivated $\mathrm{Na}^{+}$ channel include F1759 and Y1766 (F1760 and Y1767 in hH1) in DIVS6, but much data indicate that other amino acids contribute to local anesthetic binding, and more than one binding site may be present [for review, see Mike and Lukacs (2010)]. It should be noted 
that the binding site for batrachotoxin in the $\mathrm{Na}^{+}$channel vestibule overlaps that for local anesthetics (however, at a molecular weight of 539, batrachotoxin is larger than most local anesthetics) and displacement of its binding has been used to identify potential usedependent $\mathrm{Na}^{+}$channel blockers (Carter et al. 2000; Grauert et al. 2002).

The antiarrhythmic effects of drugs and agents that reduce late $I_{\mathrm{Na}}$ have been demonstrated by many investigators using many different cardiac preparations (e.g., (Antzelevitch et al. 2004, 2011; Ruan et al. 2009; Undrovinas et al. 1999; Wu et al. 2004; Sicouri et al. 1997a; Scirica et al. 2007; Antzelevitch and Belardinelli 2006; Song et al. 2004; Sheu and Lederer 1985; Fedida et al. 2006; Burashnikov et al. 2007; Pignier et al. 2010)). In these studies, late $I_{\mathrm{Na}}$ is enhanced as a result of disease (e.g., heart failure), ischemia or hypoxia, gain-offunction mutations in SCN5A, or application of toxins (e.g., ATX-II, veratridine, aconitine), intermediary metabolites (e.g., palmitoyl---carnitine), or $\mathrm{H}_{2} \mathrm{O}_{2}$. Inhibition of late $I_{\mathrm{Na}}$ has been shown to improve function and reduce arrhythmogenic activity in ventricular, atrial, pulmonary vein sleeve, and nodal cardiac tissues. Diastolic depolarization, triggered activity (EADs, DADs), AP duration and variability, and cytosolic concentrations of $\mathrm{Na}^{+}$and $\mathrm{Ca}^{2+}$ are reduced following inhibition of a pathologically enhanced late $I_{\mathrm{Na}}$. Reduction of late $I_{\mathrm{Na}}$ increases repolarization reserve (shortens AP duration) and attenuates the proarrhythmic effects of $I_{\mathrm{Kr}}$ blockers. Spontaneous and pause-triggered arrhythmic activity (i.e., $T d P$ ) induced by amiodarone, quinidine, moxifloxacin, cisapride, and ziprasidone in the female rabbit isolated heart is reduced by the late $I_{\mathrm{Na}}$ inhibitor ranolazine (Wu et al. 2006, 2008b, c). In the dog heart, inhibition of late $I_{\mathrm{Na}}$ reduces AP duration more in myocytes with longer AP durations (Purkinje fibers and M cells) than in myocytes with short AP duration (epicardial cells) and thus decreases the transmural dispersion of repolarization (Antzelevitch and Belardinelli 2006; Shimizu and Antzelevitch 1997b). No risks associated with the block of cardiac late $I_{\mathrm{Na}}$ have been identified to date.

GS-458967, a recently introduced Gilead Sciences compound, is a selective late $I_{\mathrm{Na}}$ inhibitor with an $\mathrm{IC}_{50}$ of $200 \mathrm{nM}$. The compound was shown to cause modest abbreviation of APD and to prevent or abolish both ATX-II and E-4031-induced (i.e., models of LQT3 and LQT2, respectively) ventricular tachycardias in rabbit hearts (Belardinelli et al. 2013). Other recent studies have also demonstrated the effect of GS-458967 to abolish EADs and EAD-induced triggered activity elicited by exposure of canine Purkinje fibers to ATX-II (Fig. 5), increased extracellular calcium, and isoproterenol (Sicouri et al. 2013). GS-458967 may be useful to confirm the pathologic roles of late $I_{\mathrm{Na}}$ and to investigate physiologic and pathologic effects of inhibiting late $I_{\mathrm{Na}}$ in other excitable tissues.

\section{Conclusion}

Evidence implicating enhancement of late $I_{\mathrm{Na}}$ in pathophysiological electrical and mechanical instabilities of the heart is steadily increasing (Fig. 6). Selective inhibition of late $I_{\mathrm{Na}}$ is expected to be an effective strategy for correcting these channelopathies and cardiomyopathies. Unlike most other antiarrhythmic drugs, selective inhibitors of late $I_{\mathrm{Na}}$ do not appear to be proarrhythmic. Future direction focused on development of highly selective late $I_{\mathrm{Na}}$ blockers are needed to test this hypothesis in the clinic. 


\section{Acknowledgments}

Support Supported by grants HL47678 from NHLBI, NIH (CA), C026424 from NYSTEM (CA), Gilead Sciences, Inc. and the Masons of New York State, Florida, Massachusetts Connecticut, Maryland, Rhode Island, and Wisconsin.

\section{References}

Abrahamsson C, Carlsson L, Duker G. Lidocaine and nisoldipine attenuate almokalant-induced dispersion of repolarization and early afterdepolarizations in vitro. J Cardiovasc Electrophysiol. 1996; 7:1074-1081. [PubMed: 8930739]

Abriel H. Cardiac sodium channel $\mathrm{Na}(\mathrm{v}) 1.5$ and interacting proteins: physiology and pathophysiology. J Mol Cell Cardiol. 2010; 48:2-11. [PubMed: 19744495]

Ackerman MJ, Mohler PJ. Defining a new paradigm for human arrhythmia syndromes: phenotypic manifestations of gene mutations in ion channel- and transporter-associated proteins. Circ Res. 2010; 107:457-465. [PubMed: 20724725]

Ahern GP, Hsu SF, Klyachko VA, Jackson MB. Induction of persistent sodium current by exogenous and endogenous nitric oxide. J Biol Chem. 2000; 275:28810-28815. [PubMed: 10833522]

Ahern CA, Zhang JF, Wookalis MJ, Horn R. Modulation of the cardiac sodium channel NaV1.5 by Fyn, a Src family tyrosine kinase. Circ Res. 2005; 96:991-998. [PubMed: 15831816]

Ai X, Curran JW, Shannon TR, Bers DM, Pogwizd SM. Ca2+/calmodulin-dependent protein kinase modulates cardiac ryanodine receptor phosphorylation and sarcoplasmic reticulum $\mathrm{Ca} 2+$ leak in heart failure. Circ Res. 2005; 97:1314-1322. [PubMed: 16269653]

Aiba T, Hesketh GG, Liu T, Carlisle R, Villa-Abrille MC, O'Rourke B, Akar FG, Tomaselli GF. Na+ channel regulation by $\mathrm{Ca} 2+/$ calmodulin and $\mathrm{Ca} 2+/$ calmodulin-dependent protein kinase II in guinea-pig ventricular myocytes. Cardiovasc Res. 2010; 85:454-463. [PubMed: 19797425]

Amin AS, Tan HL, Wilde AAM. Cardiac ion channels in health and disease. Heart Rhythm. 2010; 7:117-135. [PubMed: 19875343]

Anderson ME, Braun AP, Wu Y, Lu T, Wu Y, Schulman H, Sung RJ. KN-93, an inhibitor of multifunctional $\mathrm{Ca}++/$ calmodulin-dependent protein kinase, decreases early afterdepolarizations in rabbit heart. J Pharmacol Exp Ther. 1998; 287:996-1006. [PubMed: 9864285]

Anderson ME, Brown JH, Bers DM. CaMKII in myocardial hypertrophy and heart failure. J Mol Cell Cardiol. 2011; 51:468-473. [PubMed: 21276796]

Antzelevitch C. Heterogeneity and cardiac arrhythmias: an overview. Heart Rhythm. 2007; 4:964-972. [PubMed: 17599687]

Antzelevitch C. Drug-induced spatial dispersion of repolarization. Cardiol J. 2008; 15:100-121. [PubMed: 18651395]

Antzelevitch C, Belardinelli L. The role of sodium channel current in modulating transmural dispersion of repolarization and arrhythmogenesis. J Cardiovasc Electrophysiol. 2006; 17(Suppl 1):S79-S85. [PubMed: 16686686]

Antzelevitch C, Oliva A. Amplification of spatial dispersion of repolarization underlies sudden cardiac death associated with catecholaminergic polymorphic VT, long QT, short QT and Brugada syndromes. J Intern Med. 2006; 259:48-58. [PubMed: 16336513]

Antzelevitch C, Sicouri S. Mechanisms underlying arrhythmogenesis in long QT syndrome. Card Electrophysiol Clin. 2012; 4:17-27.

Antzelevitch C, Shimizu W, Yan GX, Sicouri S, Weissenburger J, Nesterenko VV, Burashnikov A, Di Diego JM, Saffitz J, Thomas GP. The M cell: its contribution to the ECG and to normal and abnormal electrical function of the heart. J Cardiovasc Electrophysiol. 1999; 10:1124-1152. [PubMed: 10466495]

Antzelevitch C, Belardinelli L, Zygmunt AC, Burashnikov A, Di Diego JM, Fish JM, Cordeiro JM, Thomas GP. Electrophysiologic effects of ranolazine: a novel anti-anginal agent with antiarrhythmic properties. Circulation. 2004; 110:904-910. [PubMed: 15302796] 
Antzelevitch, C.; Guerchicoff, A.; Pollevick, GD. The role of spatial dispersion of repolarization in sudden cardiac death. ISHNE World Wide Internet Symposium on Sudden Cardiac Death; 2006. http://hf2010.ishne.org/vs/scd-2006/lectures/ing_antzelevitch_charles.pdf

Antzelevitch C, Burashnikov A, Sicouri S, Belardinelli L. Electrophysiological basis for the antiarrhythmic actions of ranolazine. Heart Rhythm. 2011; 8:1281-1290. [PubMed: 21421082]

Auerbach DS, Grzda KR, Furspan PB, Sato PY, Mironov S, Jalife J. Structural heterogeneity promotes triggered activity, reflection and arrhythmogenesis in cardiomyocyte monolayers. J Physiol. 2011; 589:2363-2381. [PubMed: 21486795]

Backs J, Backs T, Neef S, Kreusser MM, Lehmann LH, Patrick DM, Grueter CE, Qi X, Richardson JA, Hill JA, Katus HA, Bassel-Duby R, Maier LS, Olson EN. The delta isoform of CaM kinase II is required for pathological cardiac hypertrophy and remodeling after pressure overload. Proc Natl Acad Sci U S A. 2009; 106:2342-2347. [PubMed: 19179290]

Barajas-Martinez H, Hu D, Goodrow RJ Jr, Joyce F, Antzelevitch C. Electrophysiologic characteristics and pharmacologic response of human cardiomyocytes isolated from a patient with hypertrophic cardiomyopathy. Pacing Clin Electrophysiol. 2013; 36:1512-1515. [PubMed: 24117780]

Barnett ME, Madgwick DK, Takemoto DJ. Protein kinase C as a stress sensor. Cell Signal. 2007; 19:1820-1829. [PubMed: 17629453]

Baruscotti M, DiFrancesco D, Robinson RB. Na(+) current contribution to the diastolic depolarization in newborn rabbit SA node cells. Am J Physiol Heart Circ Physiol. 2000; 279:H2303-H2309. [PubMed: 11045966]

Bean BP, Cohen CJ, Tsien RW. Lidocaine block of cardiac sodium channels. J Gen Physiol. 1983; 81:613-642. [PubMed: 6306139]

Belardinelli L, Antzelevitch C, Fraser H. Inhibition of late (sustained/persistent) sodium current: a potential drug target to reduce intracellular sodium-dependent calcium overload and its detrimental effects on cardiomyocyte function. Eur Heart J. 2004; (Suppl 6):i3-i7.

Belardinelli L, Shryock JC, Fraser H. Inhibition of the late sodium current as a potential cardioprotective principle: effects of the late sodium current inhibitor ranolazine. Heart. 2006; 92(Suppl 4):iv6-iv14. [PubMed: 16775092]

Belardinelli L, Liu G, Smith-Maxwell C, Wang WQ, El-Bizri N, Hirakawa R, Karpinski S, Kornyeyev D, Li CH, Hu L, Li XJ, Crumb W, Wu L, Koltun D, Zablocki J, Yao L, Dhalla AK, Rajamani S, Shryock J. A novel, potent, and selective inhibitor of cardiac late sodium current suppresses experimental arrhythmias. J Pharmacol Exp Ther. 2013; 344:23-32. [PubMed: 23010360]

Ben CE, Boutjdir M, Himel HD, El-Sherif N. Role of subendocardial Purkinje network in triggering torsade de pointes arrhythmia in experimental long QT syndrome. Europace. 2008; 10:1218-1223. [PubMed: 18757866]

Benito B, Brugada R, Perich RM, Lizotte E, Cinca J, Mont L, Berruezo A, Tolosana JM, Freixa X, Brugada P, Brugada J. A mutation in the sodium channel is responsible for the association of long QT syndrome and familial atrial fibrillation. Heart Rhythm. 2008; 5:1434-1440. [PubMed: 18929331]

Bennett PB, Yazawa K, Makita N, George AL Jr. Molecular mechanism for an inherited cardiac arrhythmia. Nature. 1995; 376:683-685. [PubMed: 7651517]

Benoist D, Stones R, Drinkhill MJ, Benson AP, Yang Z, Cassan C, Gilbert SH, Saint DA, Cazorla O, Steele DS, Bernus O, White E. Cardiac arrhythmia mechanisms in rats with heart failure induced by pulmonary hypertension. Am J Physiol Heart Circ Physiol. 2012; 302:H2381-H2395. [PubMed: 22427523]

Blaufox AD, Tristani-Firouzi M, Seslar S, Sanatani S, Trivedi B, Fischbach P, Paul T, Young ML, Tisma-Dupanovic S, Silva J, Cuneo B, Fournier A, Singh H, Tanel RE, Etheridge SP. Congenital long QT 3 in the pediatric population. Am J Cardiol. 2012; 109:1459-1465. [PubMed: 22360817]

Boutjdir M, El-Sherif N. Pharmacological evaluation of early afterdepolarisations induced by sea anemone toxin (ATXII) in dog heart. Cardiovasc Res. 1991; 25:815-819. [PubMed: 1684137]

Bryant SM, Wan X, Shipsey SJ, Hart G. Regional differences in the delayed rectifier current $\left(\mathrm{I}_{\mathrm{Kr}}\right.$ and $\mathrm{I}_{\mathrm{Ks}}$ ) contribute to the differences in action potential duration in basal left ventricular myocytes in guinea-pig. Cardiovasc Res. 1998; 40:322-331. [PubMed: 9893726] 
Burashnikov A, Di Diego JM, Zygmunt AC, Belardinelli L, Antzelevitch C. Atrium-selective sodium channel block as a strategy for suppression of atrial fibrillation: differences in sodium channel inactivation between atria and ventricles and the role of ranolazine. Circulation. 2007; 116:14491457. [PubMed: 17785620]

Burnes JE, Ghanem RN, Waldo AL, Rudy Y. Imaging dispersion of myocardial repolarization, I: comparison of body- surface and epicardial measures. Circulation. 2001; 104:1299-1305. [PubMed: 11551883]

Capogrossi MC, Houser SR, Bahinski A, Lakatta EG. Synchronous occurrence of spontaneous localized calcium release from the sarcoplasmic reticulum generates action potentials in rat cardiac ventricular myocytes at normal resting membrane potential. Circ Res. 1987; 61:498-503. [PubMed: 3652397]

Carmeliet E. Slow inactivation of the sodium current in rabbit cardiac Purkinje fibers. Pflugers Arch. 1987a; 408:18-26. [PubMed: 2434919]

Carmeliet E. Voltage-dependent block by tetrodotoxin of the sodium channel in rabbit cardiac Purkinje fibers. Biophys J. 1987b; 51:109-114. [PubMed: 2432950]

Carter AJ, Grauert M, Pschorn U, Bechtel WD, Bartmann-Lindholm C, Qu Y, Scheuer T, Catterall WA, Weiser T. Potent blockade of sodium channels and protection of brain tissue from ischemia by BIII 890 CL. Proc Natl Acad Sci U S A. 2000; 97:4944-4949. [PubMed: 10781102]

Chaitman BR. Ranolazine for the treatment of chronic angina and potential use in other cardiovascular conditions. Circulation. 2006; 113:2462-2472. [PubMed: 16717165]

Chandler NJ, Greener ID, Tellez JO, Inada S, Musa H, Molenaar P, DiFrancesco D, Baruscotti M, Longhi R, Anderson RH, Billeter R, Sharma V, Sigg DC, Boyett MR, Dobrzynski H. Molecular architecture of the human sinus node: insights into the function of the cardiac pacemaker. Circulation. 2009; 119:1562-1575. [PubMed: 19289639]

Chandra R, Starmer CF, Grant AO. Multiple effects of KPQ deletion mutation on gating of human cardiac Na+ channels expressed in mammalian cells. Am J Physiol. 1998; 274:H1643-H1654. [PubMed: 9612375]

Chen YJ, Chen SA, Chang MS, Lin CI. Arrhythmogenic activity of cardiac muscle in pulmonary veins of the dog: implication for the genesis of atrial fibrillation. Cardiovasc Res. 2000; 48:265-273. [PubMed: 11054473]

Cheung DW. Electrical activity of the pulmonary vein and its interaction with the right atrium in the guinea-pig. J Physiol. 1981; 314:445-456. [PubMed: 7310698]

Clancy CE, Rudy Y. Linking a genetic defect to its cellular phenotype in a cardiac arrhythmia. Nature. 1999; 400:566-569. [PubMed: 10448858]

Clancy CE, Tateyama M, Kass RS. Insights into the molecular mechanisms of bradycardia-triggered arrhythmias in long QT-3 syndrome. J Clin Invest. 2002; 110:1251-1262. [PubMed: 12417563]

Colatsky TJ. Mechanisms of action of lidocaine and quinidine on action potential duration in rabbit cardiac Purkinje fibers: an effect on steady-state sodium current? Circ Res. 1982; 50:17-27. [PubMed: 6274542]

Coppini R, Ferrantini C, Yao L, Fan P, Del LM, Stillitano F, Sartiani L, Tosi B, Suffredini S, Tesi C, Yacoub M, Olivotto I, Belardinelli L, Poggesi C, Cerbai E, Mugelli A. Late sodium current inhibition reverses electromechanical dysfunction in human hypertrophic cardiomyopathy. Circulation. 2013; 127:575-584. [PubMed: 23271797]

Coraboeuf E, Deroubaix E, Coulombe A. Effect of tetrodotoxin on action potentials of the conducting system in the dog heart. Am J Physiol. 1979; 236:H561-H567. [PubMed: 434221]

Curran J, Brown KH, Santiago DJ, Pogwizd S, Bers DM, Shannon TR. Spontaneous Ca waves in ventricular myocytes from failing hearts depend on $\mathrm{Ca}(2+)$-calmodulin-dependent protein kinase II. J Mol Cell Cardiol. 2010; 49:25-32. [PubMed: 20353795]

Damiano BP, Stump GL, Yagel SK. Investigation of electrophysiologic mechanisms for the antiarrhythmic actions of R 56865 in cardiac glycoside toxicity. J Cardiovasc Pharmacol. 1991; 18:415-428. [PubMed: 1720842]

Darbar D, Kannankeril PJ, Donahue BS, Kucera G, Stubblefield T, Haines JL, George AL Jr, Roden DM. Cardiac sodium channel (SCN5A) variants associated with atrial fibrillation. Circulation. 2008; 117:1927-1935. [PubMed: 18378609] 
Denac H, Mevissen M, Scholtysik G. Structure, function and pharmacology of voltage-gated sodium channels. Naunyn Schmiedebergs Arch Pharmacol. 2000; 362:453-479. [PubMed: 11138838]

Di Diego JM, Antzelevitch C. Pinacidil-induced electrical heterogeneity and extrasystolic activity in canine ventricular tissues. Does activation of ATP-regulated potassium current promote phase 2 reentry? Circulation. 1993; 88:1177-1189. [PubMed: 7689041]

Eddlestone GT, Zygmunt AC, Antzelevitch C, Eddlestone GT, Zygmunt AC, Antzelevitch C. Larger late sodium current contributes to the longer action potential of the $\mathrm{M}$ cell in canine ventricular myocardium. Pacing Clin Electrophysiol. 1996; 19(Pt 2):569. Abstract.

Edrich T, Wang SY, Wang GK. State-dependent block of human cardiac hNav1.5 sodium channels by propafenone. J Membr Biol. 2005; 207:35-43. [PubMed: 16463141]

Eigel BN, Gursahani H, Hadley RW. ROS are required for rapid reactivation of $\mathrm{Na}+/ \mathrm{Ca} 2+$ exchanger in hypoxic reoxygenated guinea pig ventricular myocytes. Am J Physiol Heart Circ Physiol. 2004; 286:H955-H963. [PubMed: 14592940]

Erickson JR, He BJ, Grumbach IM, Anderson ME. CaMKII in the cardiovascular system: sensing redox states. Physiol Rev. 2011; 91:889-915. [PubMed: 21742790]

Escande D, Coraboeuf E, Planche C, Lacour-Gayet F. Effects of potassium conductance inhibitors on spontaneous diastolic depolarization and abnormal automaticity in human atrial fibers. Basic Res Cardiol. 1986; 81:244-257. [PubMed: 3019294]

Fedida D. Vernakalant (RSD1235): a novel, atrial-selective antifibrillatory agent. Expert Opin Investig Drugs. 2007; 16:519-532.

Fedida D, Noble D, Rankin AC, Spindler AJ. The arrhythmogenic transient inward current $\mathrm{I}_{\mathrm{ti}}$ and related contraction in isolated guinea-pig ventricular myocytes. J Physiol (London). 1987; 392:523-542. [PubMed: 2451728]

Fedida D, Orth PM, Hesketh JC, Ezrin AM. The role of late I and antiarrhythmic drugs in EAD formation and termination in Purkinje fibers. J Cardiovasc Electrophysiol. 2006; 17(Suppl 1):S71S78. [PubMed: 16686685]

Ferrier GR, Saunders JH, Mendez C. A cellular mechanism for the generation of ventricular arrhythmias by acetylstrophanthidin. Circ Res. 1973; 32:600-609. [PubMed: 4713202]

Fish JM, Antzelevitch C. Cellular mechanism and arrhythmogenic potential of T-wave alternans in the Brugada syndrome. J Cardiovasc Electrophysiol. 2008; 19:301-308. [PubMed: 18031511]

Fraser H, Belardinelli L, Wang L, Light PE, McVeigh JJ, Clanachan AS. Ranolazine decreases diastolic calcium accumulation caused by ATX-II or ischemia in rat hearts. J Mol Cell Cardiol. 2006; 41:1031-1038. [PubMed: 17027025]

Fujiwara K, Tanaka H, Mani H, Nakagami T, Takamatsu T. Burst emergence of intracellular $\mathrm{Ca}^{2+}$ waves evokes arrhythmogenic oscillatory depolarization via the $\mathrm{Na}^{+}-\mathrm{Ca}^{2+}$ exchanger: simultaneous confocal recording of membrane potential and intracellular $\mathrm{Ca}^{2+}$ in the heart. Circ Res. 2008; 103:509-518. [PubMed: 18635824]

Galinier M, Vialette JC, Fourcade J, Cabrol P, Dongay B, Massabuau P, Boveda S, Doazan JP, Fauvel JM, Bounhoure JP. QT interval dispersion as a predictor of arrhythmic events in congestive heart failure. Importance of aetiology. Eur Heart J. 1998; 19:1054-1062. [PubMed: 9717041]

Gautier M, Zhang H, Fearon IM. Peroxynitrite formation mediates LPC-induced augmentation of cardiac late sodium currents. J Mol Cell Cardiol. 2008; 44:241-251. [PubMed: 17961592]

Gavillet B, Rougier JS, Domenighetti AA, Behar R, Boixel C, Ruchat P, Lehr HA, Pedrazzini T, Abriel H. Cardiac sodium channel Nav1.5 is regulated by a multiprotein complex composed of syntrophins and dystrophin. Circ Res. 2006; 99:407-414. [PubMed: 16857961]

Gelband H, Bush HL, Rosen MR, Myerburg RJ, Hoffman BF. Electrophysiologic properties of isolated preparations of human atrial myocardium. Circ Res. 1972; 30:293-300. [PubMed: 5060431]

Ghanem RN, Burnes JE, Waldo AL, Rudy Y. Imaging dispersion of myocardial repolarization, II: noninvasive reconstruction of epicardial measures. Circulation. 2001; 104:1306-1312. [PubMed: 11551884]

Glass A, Sicouri S, Antzelevitch C. Development of a coronary-perfused interventricular septal preparation as a model for studying the role of the septum in arrhythmogenesis. J Electrocardiol. 2007; 40:S142-S144. [PubMed: 17993311] 
Grant AO, Trantham JL, Brown KK, Strauss HC. pH-dependent effects of quinidine on the kinetics of $\mathrm{dV} / \mathrm{dt}_{\max }$ in guinea pig ventricular myocardium. Circ Res. 1982; 50:210-217. [PubMed: 7055855]

Grant AO, Dietz MA, Gilliam FR III, Starmer CF. Blockade of cardiac sodium channels by lidocaine. Single-channel analysis. Circ Res. 1989; 65:1247-1262. [PubMed: 2553292]

Grauert M, Bechtel WD, Weiser T, Stransky W, Nar H, Carter AJ. Synthesis and structure-activity relationships of 6,7-benzomorphan derivatives as use-dependent sodium channel blockers for the treatment of stroke. J Med Chem. 2002; 45:3755-3764. [PubMed: 12166948]

Guo T, Zhang T, Mestril R, Bers DM. Ca2+/calmodulin-dependent protein kinase II phosphorylation of ryanodine receptor does affect calcium sparks in mouse ventricular myocytes. Circ Res. 2006; 99:398-406. [PubMed: 16840718]

Guo D, Young LH, Wu Y, Belardinelli L, Kowey PR, Yan GX. Increased late sodium current in left atrial myocytes of rabbits with left ventricular hypertrophy: its role in the genesis of atrial arrhythmias. Am J Physiol Heart Circ Physiol. 2010; 298:H1375-H1381. [PubMed: 20190097]

Haigney MC, Lakatta EG, Stern MD, Silverman HS. Sodium channel blockade reduces hypoxic sodium loading and sodium-dependent calcium loading. Circulation. 1994; 90:391-399. [PubMed: 8026023]

Hammarstrom AK, Gage PW. Hypoxia and persistent sodium current. Eur Biophys J. 2002; 31:323330. [PubMed: 12202908]

Harris DR, Green WL, Craelius W. Acute thyroid hormone promotes slow inactivation of sodium current in neonatal cardiac myocytes. Biochim Biophys Acta. 1991; 1095:175-181. [PubMed: 1657196]

Hartmann HA, Tiedeman AA, Chen S-F, Brown AM, Kirsch GE. Effects of III-IV linker mutations on human heart $\mathrm{Na}^{+}$channel inactivation gating. Circ Res. 1994; 75:114-122. [PubMed: 8013069]

Heath BM, Cui Y, Worton S, Lawton B, Ward G, Ballini E, Doe CP, Ellis C, Patel BA, McMahon NC. Translation of flecainide- and mexiletine-induced cardiac sodium channel inhibition and ventricular conduction slowing from nonclinical models to clinical. J Pharmacol Toxicol Methods. 2011; 63:258-268. [PubMed: 21194571]

Hoch B, Meyer R, Hetzer R, Krause EG, Karczewski P. Identification and expression of deltaisoforms of the multifunctional $\mathrm{Ca} 2+/$ calmodulin-dependent protein kinase in failing and nonfailing human myocardium. Circ Res. 1999; 84:713-721. [PubMed: 10189359]

Hoeker GS, Katra RP, Wilson LD, Plummer BN, Laurita KR. Spontaneous calcium release in tissue from the failing canine heart. Am J Physiol Heart Circ Physiol. 2009; 297:H1235-H1242. [PubMed: 19648256]

Hogan PM, Davis LD. Evidence for specialized fibers in the canine right atrium. Circ Res. 1968; 23:387-396. [PubMed: 5676451]

Honerjager P. Cardioactive substances that prolong the open state of sodium channels. Rev Physiol Biochem Pharmacol. 1982; 92:1-74. [PubMed: 6278559]

Hove-Madsen L, Llach A, Bayes-Genis A, Roura S, Rodriguez FE, Aris A, Cinca J. Atrial fibrillation is associated with increased spontaneous calcium release from the sarcoplasmic reticulum in human atrial myocytes. Circulation. 2004; 110:1358-1363. [PubMed: 15313939]

Hoyer K, Song Y, Wang D, Phan D, Balser J, Ingwall JS, Belardinelli L, Shryock JC. Reducing the late sodium current improves cardiac fuction during sodium pump inhibition by ouabain. $\mathbf{J}$ Pharmacol Exp Ther. 2011; 337:513-523. [PubMed: 21325441]

Hund TJ, Koval OM, Li J, Wright PJ, Qian L, Snyder JS, Gudmundsson H, Kline CF, Davidson NP, Cardona N, Rasband MN, Anderson ME, Mohler PJ. A beta(IV)-spectrin/CaMKII signaling complex is essential for membrane excitability in mice. J Clin Invest. 2010; 120:3508-3519. [PubMed: 20877009]

Inomata N, Ishihara T. Mechanism of inhibition by SUN 1165, a new Na channel blocking antiarrhythmic agent, of cardiac glycoside-induced triggered activity. Eur J Pharmacol. 1988; 145:313-322. [PubMed: 2450764]

Isenberg G, Ravens U. The effects of the anemonia sulcata toxin (ATX II) on membrane currents of isolated mammalian myocytes. J Physiol. 1984; 357:127-149. [PubMed: 6150992]

Ji Y, Li B, Reed TD, Lorenz JN, Kaetzel MA, Dedman JR. Targeted inhibition of Ca2+/calmodulindependent protein kinase II in cardiac longitudinal sarcoplasmic reticulum results in decreased 
phospholamban phosphorylation at threonine 17. J Biol Chem. 2003; 278:25063-25071. [PubMed: 12692124]

Jia S, Lian J, Guo D, Xue X, Patel C, Yang L, Yuan Z, Ma A, Yan GX. Modulation of the late sodium current by the toxin, ATX-II, and ranolazine affects the reverse use-dependence and proarrhythmic liability of I(Kr) blockade. Br J Pharmacol. 2011; 164:308-316. [PubMed: 21182492]

John GW, Letienne R, Le GB, Pignier C, Vacher B, Patoiseau JF, Colpaert FC, Coulombe A. KC 12291: an atypical sodium channel blocker with myocardial antiischemic properties. Cardiovasc Drug Rev. 2004; 22:17-26. [PubMed: 14978516]

Josephson IR, Sperelakis N. Tetrodotoxin differentially blocks peak and steady-state sodium channel currents in early embryonic chick ventricular myocytes. Pflugers Arch. 1989; 414:354-359. [PubMed: 2550884]

Ju YK, Saint DA, Gage PW. Hypoxia increases persistent sodium current in rat ventricular myocytes. J Physiol. 1996; 497(Pt 2):337-347. [PubMed: 8961179]

Kass RS, Lederer WJ, Tsien RW, et al. Role of calcium ions in transient inward currents and aftercontractions induced by strophantidin in cardiac Purkinje fibers. J Physiol (London). 1978; 281:187-208. [PubMed: 702368]

Keung ECH, Aronson RS. Transmembrane action potentials and the electrocardiogram in rats with renal hypertension. Cardiovasc Res. 1981; 15:611-614. [PubMed: 6459847]

Kirchhefer U, Schmitz W, Scholz H, Neumann J. Activity of cAMP-dependent protein kinase and $\mathrm{Ca} 2+/$ calmodulin-dependent protein kinase in failing and nonfailing human hearts. Cardiovasc Res. 1999; 42:254-261. [PubMed: 10435018]

Kiyosue T, Arita M. Late sodium current and its contribution to action potential configuration in guinea pig ventricular myocytes. Circ Res. 1989; 64:389-397. [PubMed: 2536304]

Kohlhardt M, Fichtner H, Frobe U. Metabolites of the glycolytic pathway modulate the activity of single cardiac $\mathrm{Na}^{+}$channels. FASEB J. 1989; 3:1963-1967. [PubMed: 2542113]

Kort AA, Lakatta EG, Marban E, Stern MD, Wier WG. Fluctuations in intracellular calcium concentration and their effect on tonic tension in canine cardiac Purkinje fibres. J Physiol (London). 1985; 367:291-308. [PubMed: 4057100]

Le Grand B, Talmant JM, Rieu JP, Patoiseau JF, Colpaert FC, John GW. Investigation of the mechanism by which ketanserin prolongs the duration of the cardiac action potential. $\mathrm{J}$ Cardiovasc Pharmacol. 1995; 26:803-809. [PubMed: 8637196]

Li Z, Ai T, Samani K, Xi Y, Tzeng HP, Xie M, Wu S, Ge S, Taylor MD, Dong JW, Cheng J, Ackerman MJ, Kimura A, Sinagra G, Brunelli L, Faulkner G, Vatta M. A ZASP missense mutation, S196L, leads to cytoskeletal and electrical abnormalities in a mouse model of cardiomyopathy. Circ Arrhythm Electrophysiol. 2010; 3:646-656. [PubMed: 20852297]

Lipkind GM, Fozzard HA. Molecular modeling of local anesthetic drug binding by voltage-gated sodium channels. Mol Pharmacol. 2005; 68:1611-1622. [PubMed: 16174788]

Liu Y, DeFelice LJ, Mazzanti M. Na channels that remain open throughout the cardiac action potential plateau. Biophys J. 1992; 63:654-662. [PubMed: 1330034]

Liu H, Atkins J, Kass RS. Common molecular determinants of flecainide and lidocaine block of heart $\mathrm{Na}+$ channels: evidence from experiments with neutral and quaternary flecainide analogues. $\mathrm{J}$ Gen Physiol. 2003; 121:199-214. [PubMed: 12601084]

Liu X, Williams JB, Sumpter BR, Bevensee MO. Inhibition of the Na/bicarbonate cotransporter NBCe1-A by diBAC oxonol dyes relative to niflumic acid and a stilbene. J Membr Biol. 2007; 215:195-204. [PubMed: 17578633]

Lopez-Santiago LF, Meadows LS, Ernst SJ, Chen C, Malhotra JD, McEwen DP, Speelman A, Noebels JL, Maier SK, Lopatin AN, Isom LL. Sodium channel Scnlb null mice exhibit prolonged QT and RR intervals. J Mol Cell Cardiol. 2007; 43:636-647. [PubMed: 17884088]

Lu HR, De CF. R 56 865, a Na+/Ca(2+)-overload inhibitor, protects against aconitine-induced cardiac arrhythmias in vivo. J Cardiovasc Pharmacol. 1993; 22:120-125. [PubMed: 7690083]

Ma J, Luo A, Wu L, Wan W, Zhang P, Ren Z, Zhang S, Qian C, Shryock JC, Belardinelli L. Calmodulin kinase II and protein kinase $\mathrm{C}$ mediate the effect of increased intracellular calcium to augment late sodium current in rabbit ventricular myocytes. Am J Physiol Cell Physiol. 2012; 302:C1141-C1151. [PubMed: 22189558] 
Maier LS. A novel mechanism for the treatment of angina, arrhythmias, and diastolic dysfunction: inhibition of late $\mathrm{I}_{\mathrm{Na}}$ using ranolazine. J Cardiovasc Pharmacol. 2009; 54:279-286. [PubMed: 19333133]

Maier LS, Zhang T, Chen L, DeSantiago J, Brown JH, Bers DM. Transgenic CaMKIIdeltaC overexpression uniquely alters cardiac myocyte $\mathrm{Ca} 2+$ handling: reduced SR Ca2+ load and activated SR Ca2+ release. Circ Res. 2003; 92:904-911. [PubMed: 12676813]

Maier SK, Westenbroek RE, McCormick KA, Curtis R, Scheuer T, Catterall WA. Distinct subcellular localization of different sodium channel $\mathrm{a}$ and $\mathrm{b}$ subunits in single ventricular myocytes from mouse heart. Circulation. 2004; 109:1421-1427. [PubMed: 15007009]

Makielski JC, Farley AL. $\mathrm{Na}(+)$ current in human ventricle: implications for sodium loading and homeostasis. J Cardiovasc Electrophysiol. 2006; 17(Suppl 1):S15-S20. [PubMed: 16686671]

Makita N, Horie M, Nakamura T, Ai T, Sasaki K, Yokoi H, Sakurai M, Sakuma I, Otani H, Sawa H, Kitabatake A. Drug-induced long-QT syndrome associated with a subclinical SCN5A mutation. Circulation. 2002; 106:1269-1274. [PubMed: 12208804]

Makita N, Behr E, Shimizu W, Horie M, Sunami A, Crotti L, Schulze-Bahr E, Fukuhara S, Mochizuki N, Makiyama T, Itoh H, Christiansen M, McKeown P, Miyamoto K, Kamakura S, Tsutsui H, Schwartz PJ, George AL Jr, Roden DM. The E1784K mutation in SCN5A is associated with mixed clinical phenotype of type 3 long QT syndrome. J Clin Invest. 2008; 118:2219-2229. [PubMed: 18451998]

Maltsev VA, Undrovinas AI. A multi-modal composition of the late Na+ current in human ventricular cardiomyocytes. Cardiovasc Res. 2006; 69:116-127. [PubMed: 16223473]

Maltsev VA, Sabbah HN, Higgins RS, Silverman N, Lesch M, Undrovinas AI. Novel, ultraslow inactivating sodium current in human ventricular cardiomyocytes. Circulation. 1998; 98:25452552. [PubMed: 9843461]

Maltsev VA, Sabbah HN, Undrovinas AI. Late sodium current is a novel target for amiodarone: studies in failing human myocardium. J Mol Cell Cardiol. 2001; 33:923-932. [PubMed: 11343415]

Maltsev VA, Silverman N, Sabbah HN, Undrovinas AI. Chronic heart failure slows late sodium current in human and canine ventricular myocytes: implications for repolarization variability. Eur J Heart Fail. 2007; 9:219-227. [PubMed: 17067855]

Maltsev VA, Reznikov V, Undrovinas NA, Sabbah HN, Undrovinas A. Modulation of late sodium current by $\mathrm{Ca}^{2+}$, calmodulin, and CaMKII in normal and failing dog cardiomyocytes: similarities and differences. Am J Physiol Heart Circ Physiol. 2008; 294:H1597-H1608. [PubMed: 18203851]

Maltsev VA, Kyle JW, Undrovinas A. Late $\mathrm{Na}^{+}$current produced by human cardiac $\mathrm{Na}^{+}$channel isoform $\mathrm{Na}_{\mathrm{V}} 1.5$ is modulated by its $\mathrm{b}_{1}$ subunit. J Physiol Sci. 2009; 59:217-225. [PubMed: 19340536]

Marban E, Robinson SW, Wier WG. Mechanism of arrhythmogenic delayed and early afterdepolarizations in ferret muscle. J Clin Invest. 1986; 78:1185-1192. [PubMed: 3771791]

Mary-Rabine L, Hordof AJ, Danilo P, Malm JR, Rosen MR. Mechanisms for impulse initiation in isolated human atrial fibers. Circ Res. 1980; 47:267-277. [PubMed: 7397958]

Mazzone A, Strege PR, Tester DJ, Bernard CE, Faulkner G, Degiorgio R, Makielski JC, Stanghellini V, Gibbons SJ, Ackerman MJ, Farrugia G. A mutation in telethonin alters $\mathrm{Na}_{\mathrm{V}} 1.5$ function. J Biol Chem. 2008; 283:16537-16544. [PubMed: 18408010]

McNair WP, Ku L, Taylor MR, Fain PR, Dao D, Wolfel E, Mestroni L. SCN5A mutation associated with dilated cardiomyopathy, conduction disorder, and arrhythmia1. Circulation. 2004; 110:2163-2167. [PubMed: 15466643]

Meadows LS, Isom LL. Sodium channels as macromolecular complexes: implications for inherited arrhythmia syndromes. Cardiovasc Res. 2005; 67:448-458. [PubMed: 15919069]

Medeiros-Domingo A, Kaku T, Tester DJ, Iturralde-Torres P, Itty A, Ye B, Valdivia C, Ueda K, Canizales-Quinteros S, Tusie-Luna MT, Makielski JC, Ackerman MJ. SCN4B-encoded sodium channel b4 subunit in congenital long-QT syndrome. Circulation. 2007; 116:134-142. [PubMed: 17592081] 
Mike A, Lukacs P. The enigmatic drug binding site for sodium channel inhibitors. Curr Mol Pharmacol. 2010; 3:129-144. [PubMed: 20565383]

Milberg P, Reinsch N, Wasmer K, Monnig G, Stypmann J, Osada N, Breithardt G, Haverkamp W, Eckardt L. Transmural dispersion of repolarization as a key factor of arrhythmogenicity in a novel intact heart model of LQT3. Cardiovasc Res. 2005; 65:397-404. [PubMed: 15639478]

Mines GR. On circulating excitations in heart muscles and their possible relation to tachycardia and fibrillation. Trans R Soc Can. 1914; 8:43-52.

Mohler PJ, Splawski I, Napolitano C, Bottelli G, Sharpe L, Timothy K, Priori SG, Keating MT, Bennett V. A cardiac arrhythmia syndrome caused by loss of ankyrin-B function. Proc Natl Acad Sci U S A. 2004; 10:9137-9142. [PubMed: 15178757]

Moreno JD, Clancy CE. Pathophysiology of the cardiac late Na current and its potential as a drug target. J Mol Cell Cardiol. 2012; 52:608-619. [PubMed: 22198344]

Morrow DA. MERLIN-TIMI-36 (Metabolic Efficiency with Ranolazine for Less Ischemia in NSTE ACS). Clin Cardiol. 2007; 30:418-419.

Moss AJ, Zareba W, Schwarz KQ, Rosero S, McNitt S, Robinson JL. Ranolazine shortens repolarization in patients with sustained inward sodium current due to type-3 long-QT syndrome. J Cardiovasc Electrophysiol. 2008; 19:1289-1293. [PubMed: 18662191]

Murray KT, Hu NN, Daw JR, Shin HG, Watson MT, Mashburn AB, George AL Jr. Functional effects of protein kinase $\mathrm{C}$ activation on the human cardiac $\mathrm{Na}^{+}$channel. Circ Res. 1997; 80:370-376. [PubMed: 9048657]

Narahashi T. Tetrodotoxin: a brief history. Proc Jpn Acad Ser B Phys Biol Sci. 2008; 84:147-154.

Neef S, Dybkova N, Sossalla S, Ort KR, Fluschnik N, Neumann K, Seipelt R, Schondube FA, Hasenfuss G, Maier LS. CaMKII-dependent diastolic SR Ca2+ leak and elevated diastolic Ca2+ levels in right atrial myocardium of patients with atrial fibrillation. Circ Res. 2010; 106:11341144. [PubMed: 20056922]

Nesterenko VV, Zygmunt AC, Rajamani S, Belardinelli L, Antzelevitch C. Mechanisms of atrialselective block of $\mathrm{Na}+$ channels by ranolazine: II. Insights from a mathematical model. Am J Physiol Heart Circ Physiol. 2011; 301:H1615-H1624. [PubMed: 21821780]

Noble D, Noble PJ. Late sodium current in the pathophysiology of cardiovascular disease: consequences of sodium-calcium overload. Heart. 2006; 92(Suppl 4):iv1-iv5. [PubMed: 16775091]

Nof E, Burashnikov A, Antzelevitch C. Cellular basis for atrial fibrillation in an experimental model of short QT1: implications for a pharmacological approach to therapy. Heart Rhythm. 2010; 7:251257. [PubMed: 20042373]

Orth PM, Hesketh JC, Mak CK, Yang Y, Lin S, Beatch GN, Ezrin AM, Fedida D. RSD1235 blocks late $\mathrm{I}(\mathrm{Na})$ and suppresses early afterdepolarizations and torsades de pointes induced by class III agents. Cardiovasc Res. 2006; 70:486-496. [PubMed: 16545351]

Patel C, Antzelevitch C. Pharmacological approach to the treatment of long and short QT syndromes. Pharmacol Ther. 2008a; 118:138-151. [PubMed: 18378319]

Patel C, Antzelevitch C. Cellular basis for arrhythmogenesis in an experimental model of the SQT1 form of the short QT syndrome. Heart Rhythm. 2008b; 5:585-590. [PubMed: 18362027]

Patlak JB, Ortiz M. Slow currents through single sodium channels of the adult rat heart. J Gen Physiol. 1985; 86:89-104. [PubMed: 2411848]

Petitprez S, Zmoos AF, Ogrodnik J, Balse E, Raad N, El-Haou S, Albesa M, Bittihn P, Luther S, Lehnart SE, Hatem SN, Coulombe A, Abriel H. SAP97 and dystrophin macromolecular complexes determine two pools of cardiac sodium channels Nav1.5 in cardiomyocytes. Circ Res. 2011; 108:294-304. [PubMed: 21164104]

Pignier C, Rougier JS, Vie B, Culie C, Verscheure Y, Vacher B, Abriel H, Le GB. Selective inhibition of persistent sodium current by F 15845 prevents ischaemia-induced arrhythmias. Br J Pharmacol. 2010; 161:79-91. [PubMed: 20718741]

Pinet C, Algalarrondo V, Sablayrolles S, Le GB, Pignier C, Cussac D, Perez M, Hatem SN, Coulombe A. Protease-activated receptor-1 mediates thrombin-induced persistent sodium current in human cardiomyocytes. Mol Pharmacol. 2008; 73:1622-1631. [PubMed: 18326052] 
Remme CA, Verkerk AO, Nuyens D, Van Ginneken AC, Belterman CN, Wilders R, van Roon MA, Tan HL, Wilde AA, Carmeliet P, de Bakker JM, Veldkamp MW, Bezzina CR. Overlap syndrome of cardiac sodium channel disease in mice carrying the equivalent mutation of human SCN5A-1795insD. Circulation. 2006; 114:2584-2594. [PubMed: 17145985]

Restivo M, Caref EB, Kozhevnikov DO, El-Sherif N. Spatial dispersion of repolarization is a key factor in the arrhythmogenicity of long QT syndrome. J Cardiovasc Electrophysiol. 2004; 15:323-331. [PubMed: 15030424]

Rivolta I, Abriel H, Tateyama M, Liu H, Memmi M, Vardas P, Napolitano C, Priori SG, Kass RS. Inherited Brugada and LQT-3 syndrome mutations of a single residue of the cardiac sodium channel confer distinct channel and clinical phenotypes. J Biol Chem. 2001; 276:30623-30630. [PubMed: 11410597]

Rodriguez P, Bhogal MS, Colyer J. Stoichiometric phosphorylation of cardiac ryanodine receptor on serine 2809 by calmodulin-dependent kinase II and protein kinase A. J Biol Chem. 2003; 278:38593-38600. [PubMed: 14514795]

Rook MB, Evers MM, Vos MA, Bierhuizen MF. Biology of cardiac sodium channel Nav1.5 expression. Cardiovasc Res. 2012; 93:12-23. [PubMed: 21937582]

Rosen MR, Danilo P Jr. Effects of tetrodotoxin, lidocaine, verapamil and AHR-266 on ouabain induced delayed afterdepolarizations in canine Purkinje fibers. Circ Res. 1980; 46:117-124. [PubMed: 7349912]

Rota M, Vassalle M. Patch-clamp analysis in canine cardiac Purkinje cells of a novel sodium component in the pacemaker range. J Physiol. 2003; 548:147-165. [PubMed: 12588904]

Ruan Y, Liu N, Priori SG. Sodium channel mutations and arrhythmias. Nat Rev Cardiol. 2009; 6:337348. [PubMed: 19377496]

Sag CM, Wadsack DP, Khabbazzadeh S, Abesser M, Grefe C, Neumann K, Opiela MK, Backs J, Olson EN, Brown JH, Neef S, Maier SK, Maier LS. Calcium/calmodulin-dependent protein kinase II contributes to cardiac arrhythmogenesis in heart failure. Circ Heart Fail. 2009; 2:664675. [PubMed: 19919992]

Saint DA. The role of the persistent $\mathrm{Na}(+)$ current during cardiac ischemia and hypoxia. J Cardiovasc Electrophysiol. 2006; 17(Suppl 1):S96-S103. [PubMed: 16686689]

Saint DA. The cardiac persistent sodium current: an appealing therapeutic target? Br J Pharmacol. 2008; 153:1133-1142. [PubMed: 18071303]

Saint DA, Ju YK, Gage PW. A persistent sodium current in rat ventricular myocytes. J Physiol (London). 1992; 453:219-231. [PubMed: 1334512]

Sakmann B, Spindler AJ, Bryant SM, Linz KW, Noble D. Distribution of a persistent sodium current across the ventricular wall in guinea-pigs. Circ Res. 2000; 87:910-914. [PubMed: 11073887]

Sarhan MF, Van PF, Ahern CA. A double tyrosine motif in the cardiac sodium channel domain III-IV linker couples calcium-dependent calmodulin binding to inactivation gating. J Biol Chem. 2009; 284:33265-33274. [PubMed: 19808664]

Sawanobori T, Hirano Y, Hiraoka M. Aconitine-induced delayed afterdepolarization in frog atrium and guinea pig papillary muscles in the presence of low concentrations of Ca2+ Jpn J Physiol. 1987; 37:59-79. [PubMed: 3497297]

Scherer D, von Lowenstern K, Zitron E, Scholz EP, Bloehs R, Kathofer S, Thomas D, Bauer A, Katus HA, Karle CA, Kiesecker C. Inhibition of cardiac hERG potassium channels by tetracyclic antidepressant mianserin. Naunyn Schmiedebergs Arch Pharmacol. 2008; 378:73-83. [PubMed: 18458880]

Scherf D, Romano FJ, Terranova R. Experimental studies on auricular flutter and auricular fibrillation. Am Heart J. 1948; 36:241-251. [PubMed: 18873261]

Schlotthauer K, Bers DM. Sarcoplasmic reticulum $\mathrm{Ca}(2+)$ release causes myocyte depolarization. Underlying mechanism and threshold for triggered action potentials. Circ Res. 2000; 87:774780. [PubMed: 11055981]

Schreibmayer W, Lindner W. Stereoselective interactions of (R)- and (S)-propafenone with the cardiac sodium channel. J Cardiovasc Pharmacol. 1992; 20:324-331. [PubMed: 1381026]

Scirica BM, Morrow DA, Hod H, Murphy SA, Belardinelli L, Hedgepeth CM, Molhoek P, Verheugt $\mathrm{FW}$, Gersh BJ, McCabe $\mathrm{CH}$, Braunwald E. Effect of ranolazine, an antianginal agent with novel 
electrophysiological properties, on the incidence of arrhythmias in patients with non ST-segment elevation acute coronary syndrome: results from the metabolic efficiency with ranolazine for less ischemia in non ST-elevation ACUTE CORONARY syndrome thrombolysis in myocardial infarction 36 (MERLIN-TIMI 36) randomized controlled trial. Circulation. 2007; 116:16471652. [PubMed: 17804441]

Shao D, Okuse K, Djamgoz MB. Protein-protein interactions involving voltage-gated sodium channels: post-translational regulation, intracellular trafficking and functional expression. Int $\mathbf{J}$ Biochem Cell Biol. 2009; 41:1471-1481. [PubMed: 19401147]

Shattock MJ, Bers DM. Rat vs. rabbit ventricle: Ca flux and intracellular Na assessed by ion-selective microelectrodes. Am J Physiol. 1989; 256:C813-C822. [PubMed: 2705515]

Sheu SS, Lederer WJ. Lidocaine's negative inotropic and antiarrhythmic actions: dependence on shortening of action potential duration and reduction of intracellular sodium activity. Circ Res. 1985; 57:578-590. [PubMed: 2412723]

Shimizu W, Antzelevitch C. Sodium channel block with mexiletine is effective in reducing dispersion of repolarization and preventing torsade de pointes in LQT2 as well as LQT3 models of the long QT syndrome. Pacing Clin Electrophysiol. 1997a; 20:1234. Abstract.

Shimizu W, Antzelevitch C. Sodium channel block with mexiletine is effective in reducing dispersion of repolarization and preventing torsade de pointes in LQT2 and LQT3 models of the long-QT syndrome. Circulation. 1997b; 96:2038-2047. [PubMed: 9323097]

Shimizu W, Antzelevitch C. Cellular basis for the ECG features of the LQT1 form of the long QT syndrome: effects of b-adrenergic agonists and antagonists and sodium channel blockers on transmural dispersion of repolarization and torsade de pointes. Circulation. 1998; 98:2314-2322. [PubMed: 9826320]

Shimizu W, Antzelevitch C. Spontaneous and stimulation-induced Torsade de Pointes in LQT1, LQT2 and LQT3 models of the long QT syndrome. Circulation. 1999a; 100(II):359. Abstract.

Shimizu W, Antzelevitch C. Cellular basis for long QT, transmural dispersion of repolarization, and Torsade de Pointes in the long QT syndrome. J Electrocardiol. 1999b; 32(Suppl):177-184. [PubMed: 10688323]

Shryock JC, Song Y, Rajamani S, Antzelevitch C, Belardinelli L. The arrhythmogenic consequences of increasing late INa in the cardiomyocyte. Cardiovasc Res. 2013; 99:600-611. [PubMed: 23752976]

Sicouri S, Fish J, Antzelevitch C. Distribution of M cells in the canine ventricle. J Cardiovasc Electrophysiol. 1994; 5:824-837. [PubMed: 7874328]

Sicouri S, Quist M, Antzelevitch C. Evidence for the presence of M cells in the guinea pig ventricle. J Cardiovasc Electrophysiol. 1996; 7:503-511. [PubMed: 8743756]

Sicouri S, Antzelevitch D, Heilmann C, Antzelevitch C. Effects of sodium channel block with mexiletine to reverse action potential prolongation in in vitro models of the long QT syndrome. $\mathrm{J}$ Cardiovasc Electrophysiol. 1997a; 8:1280-1290. [PubMed: 9395171]

Sicouri S, Moro S, Litovsky SH, Elizari MV, Antzelevitch C. Chronic amiodarone reduces transmural dispersion of repolarization in the canine heart. J Cardiovasc Electrophysiol. 1997b; 8:12691279. [PubMed: 9395170]

Sicouri S, Glass A, Ferreiro M, Antzelevitch C. Transseptal dispersion of repolarization and its role in the development of torsade de pointes arrhythmias. J Cardiovasc Electrophysiol. 2010; 21:441447. [PubMed: 19909385]

Sicouri S, Blazek J, Belardinelli L, Antzelevitch C. Electrophysiological characteristics of canine superior vena cava sleeve preparations. Effect of ranolazine. Circ Arrhythm Electrophysiol. 2012a; 5:371-379. [PubMed: 22407414]

Sicouri S, Pourrier M, Gibson JK, Lynch JJ, Antzelevitch C. Comparison of electrophysio-logical and antiarrhythmic effects of vernakalant, ranolazine, and sotalol in canine pulmonary vein sleeve preparations. Heart Rhythm. 2012b; 9:422-429. [PubMed: 22019863]

Sicouri S, Blazek J, Belardinelli L, Antzelevitch C. Antiarrhythmic effects of the highly-selective late sodium channel current blocker GS 458967 in canine Purkinje fibers and pulmonary vein sleeve preparations. Heart Rhythm. 2012c; 9:S186. Abstract. 
Sicouri S, Belardinelli L, Antzelevitch C. Antiarrhythmic effects of the highly-selective late sodium channel current blocker GS-458967. Heart Rhythm. 2013; 10(7):1036-1043. [PubMed: 23524321]

Sidorov VY, Uzelac I, Wikswo JP. Regional increase of extracellular potassium leads to electrical instability and reentry occurrence through the spatial heterogeneity of APD restitution. Am J Physiol Heart Circ Physiol. 2011; 301:H209-H220. [PubMed: 21536842]

Song JH, Huang CS, Nagata K, Yeh JZ, Narahashi T. Differential action of riluzole on tetrodotoxinsensitive and tetrodotoxin-resistant sodium channels. J Pharmacol Exp Ther. 1997; 282:707-714. [PubMed: 9262334]

Song Y, Shryock JC, Wu L, Belardinelli L. Antagonism by ranolazine of the pro-arrhythmic effects of increasing late INa in guinea pig ventricular myocytes. J Cardiovasc Pharmacol. 2004; 44:192199. [PubMed: 15243300]

Song Y, Shryock J, Wagner S, Maier LS, Belardinelli L. Blocking late sodium current reduces hydrogen peroxide-induced arrhythmogenic activity and contractile dysfunction. J Pharmacol Exp Ther. 2006; 318:214-222. [PubMed: 16565163]

Song Y, Shryock JC, Belardinelli L. An increase of late sodium current induces delayed afterdepolarizations and sustained triggered activity in atrial myocytes. Am J Physiol Heart Circ Physiol. 2008; 294:H2031-H2039. [PubMed: 18310511]

Song Y, Shryock JC, Belardinelli L. A slowly inactivating sodium current contributes to spontaneous diastolic depolarization of atrial myocytes. Am J Physiol Heart Circ Physiol. 2009; 297:H1254H1262. [PubMed: 19700626]

Sossalla S, Wagner S, Rasenack EC, Ruff H, Weber SL, Schondube FA, Tirilomis T, Tenderich G, Hasenfuss G, Belardinelli L, Maier LS. Ranolazine improves diastolic dysfunction in isolated myocardium from failing human hearts-role of late sodium current and intracellular ion accumulation. J Mol Cell Cardiol. 2008; 45:32-43. [PubMed: 18439620]

Sossalla S, Kallmeyer B, Wagner S, Mazur M, Maurer U, Toischer K, Schmitto JD, Seipelt R, Schondube FA, Hasenfuss G, Belardinelli L, Maier LS. Altered $\mathrm{Na}^{+}$currents in atrial fibrillation: effects of ranolazine on arrhythmias and contractility in human atrial myocardium. J Am Coll Cardiol. 2010; 55:2330-2342. [PubMed: 20488304]

Sossalla S, Maurer U, Schotola H, Hartmann N, Didie M, Zimmermann WH, Jacobshagen C, Wagner $\mathrm{S}$, Maier LS. Diastolic dysfunction and arrhythmias caused by overexpression of CaMKIIdelta(C) can be reversed by inhibition of late $\mathrm{Na}(+)$ current. Basic Res Cardiol. 2011; 106:263-272. [PubMed: 21174213]

Spencer CI, Sham JS. Mechanisms underlying the effects of the pyrethroid, tefluthrin, on action potential duration in isolated rat ventricular myocytes 1. J Pharmacol Exp Ther. 2005; 315:1623. [PubMed: 15980056]

Splawski I, Timothy KW, Tateyama M, Clancy CE, Malhotra A, Beggs AH, Cappuccio FP, Sagnella GA, Kass RS, Keating MT. Variant of SCN5A sodium channel implicated in risk of cardiac arrhythmia. Science. 2002; 297:1333-1336. [PubMed: 12193783]

Starmer CF, Nesterenko VV, Undrovinas AI, Grant AO, Rosenshtraukh LV. Lidocaine blockade of continuously and transiently accessible sites in cardiac sodium channels. J Mol Cell Cardiol. 1991; 23(Suppl I):73-83. [PubMed: 1645414]

Stern MD, Capogrossi MC, Lakatta EG. Spontaneous calcium release from the sarcoplasmic reticulum in myocardial cells: mechanisms and consequences. Cell Calcium. 1988; 9:247-256. [PubMed: 3066490]

Sunami A, Fan Z, Sawanobori T, Hiraoka M. Use-dependent block of Na + currents by mexiletine at the single channel level in guinea-pig ventricular myocytes. Br J Pharmacol. 1993; 110:183-192. [PubMed: 8220878]

Tamareille S, Le GB, John GW, Feuvray D, Coulombe A. Anti-ischemic compound KC 12291 prevents diastolic contracture in isolated atria by blockade of voltage-gated sodium channels. J Cardiovasc Pharmacol. 2002; 40:346-355. [PubMed: 12198320]

Tan BH, Pundi KN, Van Norstrand DW, Valdivia CR, Tester DJ, Medeiros-Domingo A, Makielski JC, Ackerman MJ. Sudden infant death syndrome-associated mutations in the sodium channel beta subunits. Heart Rhythm. 2010; 7:771-778. [PubMed: 20226894] 
Tang L, Joung B, Ogawa M, Chen PS, Lin SF. Intracellular calcium dynamics, shortened action potential duration, and late-phase 3 early after depolarization in langendorff-perfused rabbit ventricles. J Cardiovasc Electrophysiol. 2012; 23:1364-1371. [PubMed: 22809087]

Trautwein W, Kassebaum DG, Nelson RM, HECHTHH. Electrophysiological study of human heart muscle. Circ Res. 1962; 10:306-312. [PubMed: 13922328]

Tsuchida K, Otomo S. Electrophysiological effects of Monensin, a sodium ionophore, on cardiac Purkinje fibers. Eur J Pharm. 1990; 190:313-320.

Tweedie D, Harding SE, MacLeod KT. Sarcoplasmic reticulum Ca content, sarcolemmal Ca influx and the genesis of arrhythmias in isolated guinea-pig cardiomyocytes. J Mol Cell Cardiol. 2000; 32:261-272. [PubMed: 10722802]

Ueda N, Zipes DP, Wu J. Prior ischemia enhances arrhythmogenicity in isolated canine ventricular wedge model of long QT 3. Cardiovasc Res. 2004; 63:69-76. [PubMed: 15194463]

Ueda K, Valdivia C, Medeiros-Domingo A, Tester DJ, Vatta M, Farrugia G, Ackerman MJ, Makielski JC. Syntrophin mutation associated with long QT syndrome through activation of the nNOSSCN5A macromolecular complex. Proc Natl Acad Sci U S A. 2008; 105:9355-9360. [PubMed: 18591664]

Undrovinas A, Maltsev VA. Late sodium current is a new therapeutic target to improve contractility and rhythm in failing heart. Cardiovasc Hematol Agents Med Chem. 2008a; 6:348-359. [PubMed: 18855648]

Undrovinas A, Maltsev VA. Late sodium current is a new therapeutic target to improve contractility and rhythm in failing heart. Cardiovasc Hematol Agents Med Chem. 2008b; 6:348-359. [PubMed: 18855648]

Undrovinas AI, Fleidervish IA, Makielski JC. Inward sodium current at resting potentials in single cardiac myocytes induced by the ischemic metabolite lysophosphatidylcholine. Circ Res. 1992; 71:1231-1241. [PubMed: 1327577]

Undrovinas AI, Maltsev VA, Sabbah HN. Repolarization abnormalities in cardiomyocytes of dogs with chronic heart failure: role of sustained inward current. Cell Mol Life Sci. 1999; 55:494-505. [PubMed: 10228563]

Undrovinas AI, Maltsev VA, Kyle JW, Silverman N, Sabbah HN. Gating of the late Na+ channel in normal and failing human myocardium. J Mol Cell Cardiol. 2002; 34:1477-1489. [PubMed: 12431447]

Undrovinas AI, Undrovinas NA, Belardinelli L, Sabbah HN. Ranolazine inhibits late sodium current in isolated left ventricular myocytes of dogs with heart failure. J Am Coll Cardiol. 2004; 43(supplA):178A. Abstract.

Undrovinas AI, Belardinelli L, Undrovinas NA, Sabbah HN. Ranolazine improves abnormal repolarization and contraction in left ventricular myocytes of dogs with heart failure by inhibiting late sodium current. J Cardiovasc Electrophysiol. 2006; 17:S161-S177.

Undrovinas NA, Maltsev VA, Belardinelli L, Sabbah HN, Undrovinas A. Late sodium current contributes to diastolic cell Ca2+ accumulation in chronic heart failure. J Physiol Sci. 2010; 60:245-257. [PubMed: 20490740]

Vacher B, Pignier C, Letienne R, Verscheure Y, Le GB. F 15845 inhibits persistent sodium current in the heart and prevents angina in animal models. Br J Pharmacol. 2009; 156:214-225. [PubMed: 19133985]

Valdivia CR, Chu WW, Pu J, Foell JD, Haworth RA, Wolff MR, Kamp TJ, Makielski JC. Increased late sodium current in myocytes from a canine heart failure model and from failing human heart. J Mol Cell Cardiol. 2005; 38:475-483. [PubMed: 15733907]

Vatta M, Faulkner G. Cytoskeletal basis of ion channel function in cardiac muscle. Future Cardiol. 2006; 2:467-476. [PubMed: 19774097]

Vatta M, Ackerman MJ, Ye B, Makielski JC, Ughanze EE, Taylor EW, Tester DJ, Balijepalli RC, Foell JD, Li Z, Kamp TJ, Towbin JA. Mutant caveolin-3 induces persistent late sodium current and is associated with long-QT syndrome. Circulation. 2006; 114:2104-2112. [PubMed: 17060380] 
Verdonck F, Bielen FV, Ver DL. Preferential block of the veratridine-induced, non-inactivating Na + current by R56865 in single cardiac Purkinje cells. Eur J Pharmacol. 1991; 203:371-378. [PubMed: 1663453]

Vermeulen JT, Tan HL, Rademaker H, Schumacher CA, Loh P, Opthof T, Coronel R, Janse MJ. Electrophysiologic and extracellular ionic changes during acute ischemia in failing and normal rabbit myocardium. J Mol Cell Cardiol. 1996; 28:123-131. [PubMed: 8745220]

Vollmer B, Meuter C, Janssen PA. R 56865 prevents electrical and mechanical signs of ouabain intoxication in guinea-pig papillary muscle. Eur J Pharmacol. 1987; 142:137-140. [PubMed: 3691632]

Wagner S, Dybkova N, Rasenack EC, Jacobshagen C, Fabritz L, Kirchhof P, Maier SK, Zhang T, Hasenfuss G, Brown JH, Bers DM, Maier LS. Ca2+/calmodulin-dependent protein kinase II regulates cardiac Na+ channels. J Clin Invest. 2006; 116:3127-3138. [PubMed: 17124532]

Wagner S, Ruff HM, Weber SL, Bellmann S, Sowa T, Schulte T, Anderson ME, Grandi E, Bers DM, Backs J, Belardinelli L, Maier LS. Reactive oxygen species-activated Ca/calmodulin kinase IIdelta is required for late $\mathrm{I}(\mathrm{Na})$ augmentation leading to cellular $\mathrm{Na}$ and Ca overload. Circ Res. 2011; 108:555-565. [PubMed: 21252154]

Wang Q, Shen J, Li Z, Timothy KW, Vincent GM, Priori SG, Schwartz PJ, Keating MT. Cardiac sodium channel mutations in patients with long QT syndrome, an inherited cardiac arrhythmia. Hum Mol Genet. 1995; 4:1603-1607. [PubMed: 8541846]

Wang DW, Yazawa K, George AL Jr, Bennett PB. Characterization of human cardiac $\mathrm{Na}^{+}$channel mutations in the congenital long QT syndrome. Proc Natl Acad Sci U S A. 1996; 93:1320013205. [PubMed: 8917568]

Wang DW, Crotti L, Shimizu W, Pedrazzini M, Ikeda T, Schwartz PJ, George AL. Malignant perinatal variant of long-QT syndrome caused by a profoundly dysfunctional cardiac sodium channel. Circ Arrhythm Electrophysiol. 2008; 1:370-378. [PubMed: 19808432]

Wang DW, Mistry AM, Kahlig KM, Kearney JA, Xiang J, George AL Jr. Propranolol blocks cardiac and neuronal voltage-gated sodium channels. Front Pharmacol. 2010; 1:144. [PubMed: 21833183]

Ward CA, Giles WR. Ionic mechanism of the effects of hydrogen peroxide in rat ventricular myocytes. J Physiol. 1997; 500(Pt 3):631-642. [PubMed: 9161981]

Ward CA, Bazzazi H, Clark RB, Nygren A, Giles WR. Actions of emigrated neutrophils on Na(+) and $\mathrm{K}(+)$ currents in rat ventricular myocytes. Prog Biophys Mol Biol. 2006; 90:249-269. [PubMed: 16165196]

Weiss S, Benoist D, White E, Teng W, Saint DA. Riluzole protects against cardiac ischaemia and reperfusion damage via block of the persistent sodium current. Br J Pharmacol. 2010; 160:10721082. [PubMed: 20590601]

West JW, Patton DE, Scheuer T. A cluster of hydrophobic amino acid residues required for fast $\mathrm{Na}^{+}$ channel inactivation. Proc Natl Acad Sci U S A. 1992; 89:10910-10914. [PubMed: 1332060]

Wilhelm D, Himmel H, Ravens U, Peters T. Characterization of the interaction of R 56865 with cardiac Na- and L-type Ca channels. Br J Pharmacol. 1991; 104:483-489. [PubMed: 1665739]

Wilson LD, Jeyaraj D, Wan X, Hoeker GS, Said TH, Gittinger M, Laurita KR, Rosenbaum DS. Heart failure enhances susceptibility to arrhythmogenic cardiac alternans. Heart Rhythm. 2009; 6:251259. [PubMed: 19187920]

Wit AL, Cranefield PF. Triggered and automatic activity in the canine coronary sinus. Circ Res. 1977; 41:435-445.

Wit AL, Rosen MR. Pathophysiologic mechanisms of cardiac arrhythmias. Am Heart J. 1983; 106:798-811. [PubMed: 6310978]

Witchel HJ, Dempsey CE, Sessions RB, Perry M, Milnes JT, Hancox JC, Mitcheson JS. The lowpotency, voltage-dependent HERG blocker propafenone-molecular determinants and drug trapping. Mol Pharmacol. 2004; 66:1201-1212. [PubMed: 15308760]

Wu J, Corr PB. Palmitoylcarnitine increases $[\mathrm{Na}+]$ i and initiates transient inward current in adult ventricular myocytes. Am J Physiol. 1995; 268:H2405-H2417. [PubMed: 7611493]

Wu L, Song Y, Shryock JC, Li Y, Antzelevitch C, Belardinelli L. Ranolazine attenuates the prolongation of ventricular monophasic action potential and suppresses ventricular tachycardia

Handb Exp Pharmacol. Author manuscript; available in PMC 2015 January 01. 
caused by sea anemone toxin, ATX-II, in guinea pig isolated hearts. PACE. 2003; 26:1023. Abstract.

Wu L, Shryock JC, Song Y, Li Y, Antzelevitch C, Belardinelli L. Antiarrhythmic effects of ranolazine in a guinea pig in vitro model of long-QT syndrome. J Pharmacol Exp Ther. 2004; 310:599-605. [PubMed: 15031300]

Wu L, Shryock JC, Song Y, Belardinelli L. An increase in late sodium current potentiates the proarrhythmic activities of low-risk QT-prolonging drugs in female rabbit hearts. J Pharmacol Exp Ther. 2006; 316:718-726. [PubMed: 16234410]

Wu G, Ai T, Kim JJ, Mohapatra B, Xi Y, Li Z, Abbasi S, Purevjav E, Samani K, Ackerman MJ, Qi M, Moss AJ, Shimizu W, Towbin JA, Cheng J, Vatta M. a-1-syntrophin mutation and the long-QT syndrome: a disease of sodium channel disruption. Circ Arrhythm Electrophysiol. 2008a; 1:193201. [PubMed: 19684871]

Wu L, Guo D, Li H, Hackett J, Yan GX, Jiao Z, Antzelevitch C, Shryock JC, Belardinelli L. Role of late sodium current in modulating the proarrhythmic and antiarrhythmic effects of quinidine. Heart Rhythm. 2008b; 5:1726-1734. [PubMed: 19084812]

Wu L, Rajamani S, Shryock JC, Li H, Ruskin J, Antzelevitch C, Belardinelli L. Augmentation of late sodium current unmasks the proarrhythmic effects of amiodarone. Cardiovasc Res. 2008c; 77:481-488. [PubMed: 18006430]

Wu Y, Song Y, Belardinelli L, Shryock JC. The late $\mathrm{Na}^{+}$current $\left(\mathrm{I}_{\mathrm{Na}}\right)$ inhibitor ranolazine attenuates effects of Palmitoyl-L-Carnitine to increase late $\mathrm{I}_{\mathrm{Na}}$ and cause ventricular diastolic dysfunction. J Pharmacol Exp Ther. 2009a; 330:550-557. [PubMed: 19403851]

Wu L, Rajamani S, Li H, January CT, Shryock JC, Belardinelli L. Reduction of repolarization researve unmasks the pro-arrhythmic role of endogenous late sodium current in the heart. Am J Physiol Heart Circ Physiol. 2009b; 297:H1048-H1057. [PubMed: 19592609]

Wu L, Ma J, Li H, Wang C, Grandi E, Zhang P, Luo A, Bers DM, Shryock JC, Belardinelli L. Late sodium current contributes to the reverse rate-dependent effect of IKr inhibition on ventricular repolarization. Circulation. 2011; 123:1713-1720. [PubMed: 21482963]

Xiao XH, Allen DG. Role of $\mathrm{Na}(+) / \mathrm{H}(+)$ exchanger during ischemia and preconditioning in the isolated rat heart. Circ Res. 1999; 85:723-730. [PubMed: 10521246]

Xie LH, Chen F, Karagueuzian HS, Weiss JN. Oxidative-stress-induced after depolarizations and calmodulin kinase II signaling. Circ Res. 2009; 104:79-86. [PubMed: 19038865]

Yan GX, Wu Y, Liu T, Wang J, Marinchak RA, Kowey PR. Phase 2 early afterdepolarization as a trigger of polymorphic ventricular tachycardia in acquired long-qt syndrome: direct evidence from intracellular recordings in the intact left ventricular wall. Circulation. 2001; 103:28512856. [PubMed: 11401944]

Yao L, Fan P, Jiang Z, Viatchenko-Karpinski S, Wu Y, Kornyeyev D, Hirakawa R, Budas GR, Rajamani S, Shryock JC, Belardinelli L. Nav1.5-dependent persistent Na+ influx activates CaMKII in rat ventricular myocytes and N1325S mice. Am J Physiol Cell Physiol. 2011; 301:C577-C586. [PubMed: 21677263]

Yatani A, Akaike N. Blockage of the sodium current in isolated single cells from rat ventricle with mexiletine and disopyramide. J Mol Cell Cardiol. 1985; 17:467-476. [PubMed: 2411942]

Zaza A, Belardinelli L, Shryock JC. Pathophysiology and pharmacology of the cardiac "late sodium current”. Pharmacol Ther. 2008; 119:326-339. [PubMed: 18662720]

Zeiler RH, Gough WB, El-Sherif N. Electrophysiologic effects of propafenone on canine ischemic cardiac cells. Am J Cardiol. 1984; 54:424-429. [PubMed: 6465028]

Zellerhoff S, Pistulli R, Monnig G, Hinterseer M, Beckmann BM, Kobe J, Steinbeck G, Kaab S, Haverkamp W, Fabritz L, Gradaus R, Breithardt G, Schulze-Bahr E, Bocker D, Kirchhof P. Atrial arrhythmias in long-QT syndrome under daily life conditions: a nested case control study. J Cardiovasc Electrophysiol. 2009; 20:401-407. [PubMed: 19017345]

Zhang T, Kohlhaas M, Backs J, Mishra S, Phillips W, Dybkova N, Chang S, Ling H, Bers DM, Maier LS, Olson EN, Brown JH. CaMKIIdelta isoforms differentially affect calcium handling but similarly regulate HDAC/MEF2 transcriptional responses. J Biol Chem. 2007; 282:3507835087. [PubMed: 17923476] 
Zhang XQ, Yamada S, Barry WH. Ranolazine inhibits an oxidative stress-induced increase in myocyte sodium and calcium loading during simulated-demand ischemia. J Cardiovasc Pharmacol. 2008; 51:443-449. [PubMed: 18398379]

Zhang T, Yong SL, Drinko JK, Popovic ZB, Shryock JC, Belardinelli L, Wang QK. LQTS mutation N1325S in cardiac sodium channel gene SCN5A causes cardiomyocyte apoptosis, cardiac fibrosis and contractile dysfunction in mice. Int J Cardiol. 2011; 147:239-245. [PubMed: 19762097]

Zhao G, Walsh E, Shryock JC, Messina E, Wu Y, Zeng D, Xu X, Ochoa M, Baker SP, Hintze TH, Belardinelli L. Antiadrenergic and hemodynamic effects of ranolazine in conscious dogs. J Cardiovasc Pharmacol. 2011; 57:639-647. [PubMed: 21633249]

Zicha S, Maltsev VA, Nattel S, Sabbah HN, Undrovinas AI. Post-transcriptional alterations in the expression of cardiac $\mathrm{Na}+$ channel subunits in chronic heart failure1. J Mol Cell Cardiol. 2004; 37:91-100. [PubMed: 15242739]

Zimmer T, Surber R. SCN5A channelopathies - an update on mutations and mechanisms. Prog Biophys Mol Biol. 2008; 98:120-136. [PubMed: 19027780]

Zygmunt AC, Eddlestone GT, Thomas GP, Nesterenko VV, Antzelevitch C. Larger late sodium conductance in $\mathrm{M}$ cells contributes to electrical heterogeneity in canine ventricle. Am J Physiol. 2001; 281:H689-H697.

Zygmunt AC, Nesterenko VV, Rajamani S, Hu D, Barajas-Martinez H, Belardinelli L, Antzelevitch C. Mechanisms of atrial-selective block of sodium channel by ranolazine I. Experimental analysis of the use-dependent block. Am J Physiol Heart Circ Physiol. 2011; 301:H1606-H1614. [PubMed: 21821778] 


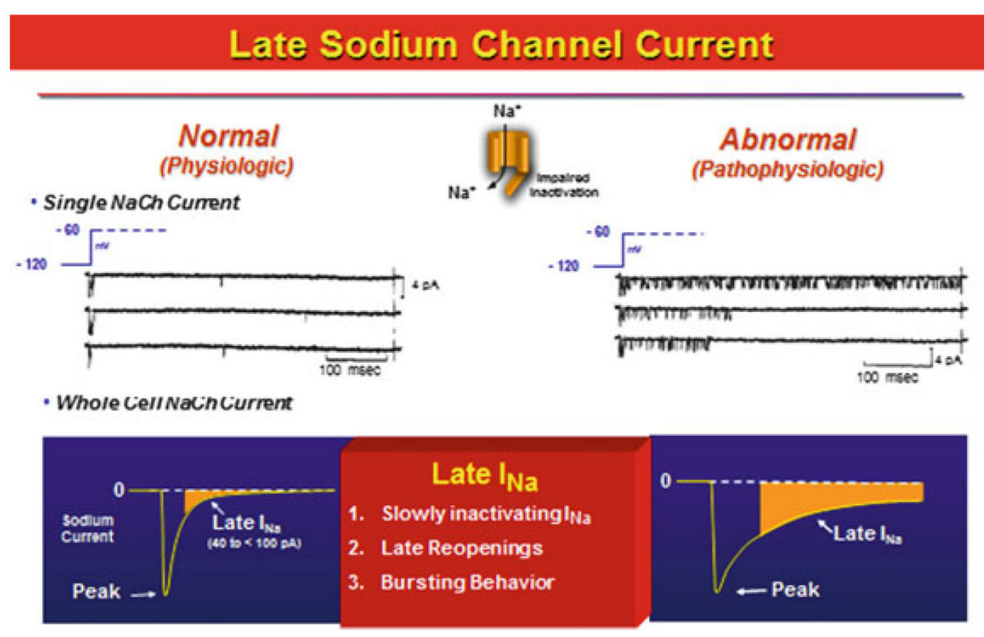

Fig. 1.

Late sodium channel current is the current flowing during the plateau of the cardiac action potential and is comprised of slowly inactivating sodium channel current, late re-openings, and bursting behavior of the sodium channels. Modified from Belardinelli et al. (2004), with permission 


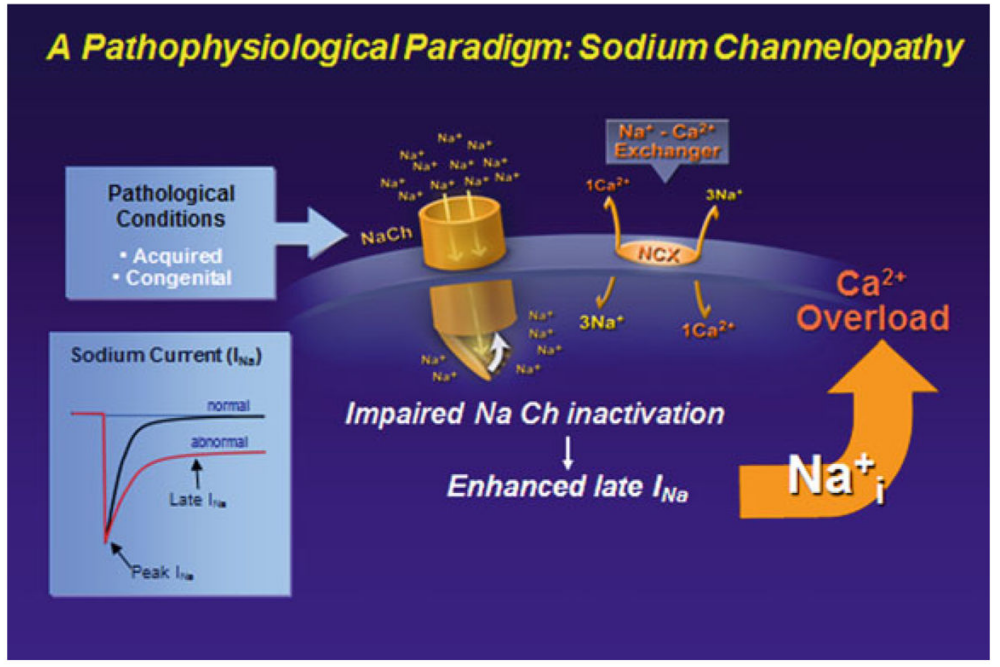

Fig. 2.

The pathophysiological paradigm for enhanced late $I_{\mathrm{Na}}$. In both acquired and congenital syndromes, impaired inactivation of the sodium channel leads to enhanced late $I_{\mathrm{Na}}$, causing a rise in intracellular $\mathrm{Na}$ concentration, which leads to calcium overload conditions. Modified from Belardinelli et al. (2006), with permission 


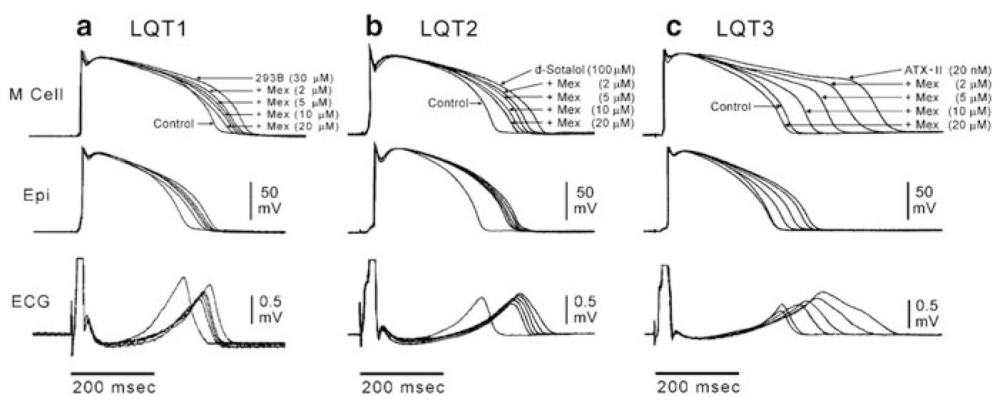

Fig. 3.

$I_{\mathrm{Kr}}$ and $I_{\mathrm{Ks}}$ blockers and Late $I_{\mathrm{Na}}$ agonist promote transmural dispersion (TDR) of repolarization and prolonged Tpeak-Tend intervals in the ECG by producing a preferential prolongation of the $\mathrm{M}$ cell action potential duration. Block of late $I_{\mathrm{Na}}$ with mexiletine reduces TDR in these experimental models of the long QT syndrome. Each panel shows transmembrane action potentials recorded from $M$ and epicardial (Epi) sites in canine left ventricular wedge preparations together with a transmural ECG recorded across the bath (BCL of 2,000 ms). Traces are recorded in the presence of the $I_{\mathrm{Ks}}$ blocker, chromanol 293B (LQT1), $I_{\mathrm{Kr}}$ blocker $\mathrm{D}$-sotalol (LQT2), and late $I_{\mathrm{Na}}$ agonist, ATX-II (LQT3), plus increasing concentrations of mexiletine. Mexiletine produced a greater abbreviation of the $\mathrm{M}$ cell vs. epicardial action potential at every concentration, resulting in a reduction in transmural dispersion of repolarization in all three LQTS models. Modified from (Shimizu and Antzelevitch 1997b, 1998) with permission 

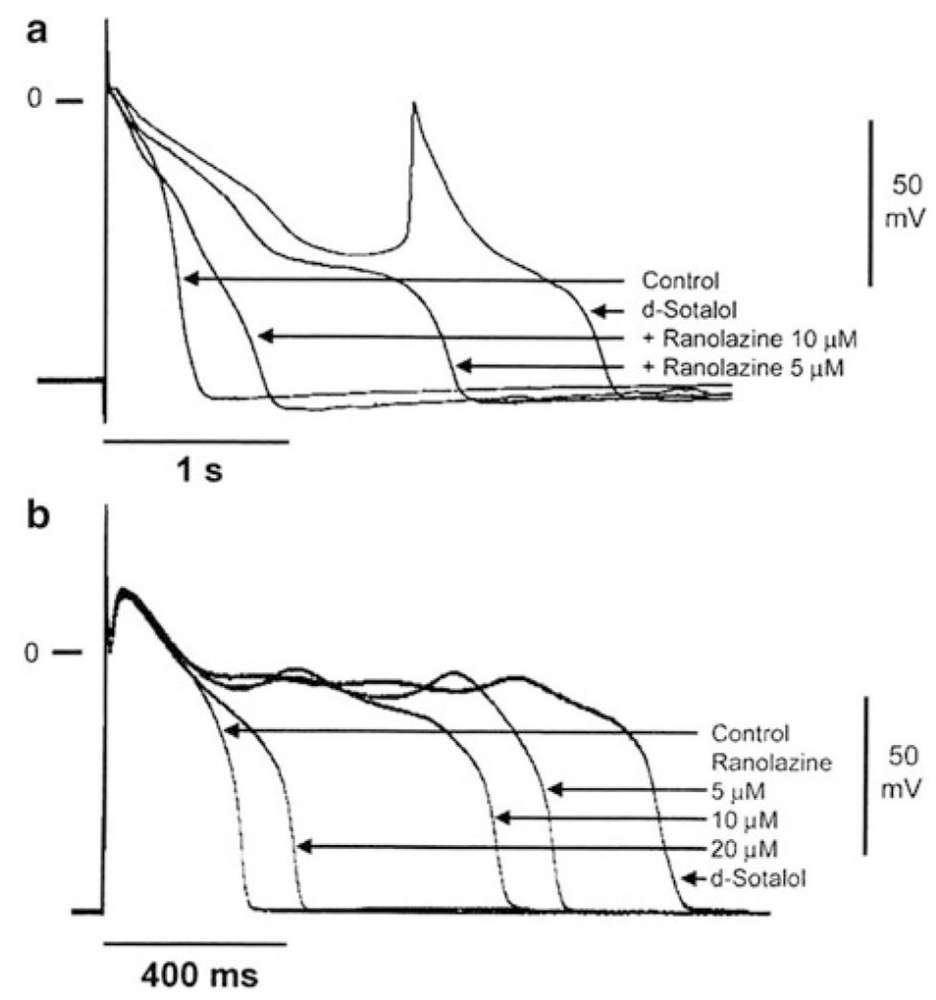

Fig. 4.

Effect of ranolazine to suppress b-sotalol-induced action potential prolongation and early afterdepolarizations in Purkinje fiber (a) and M cell preparations (b). Modified from Antzelevitch et al. (2004) 


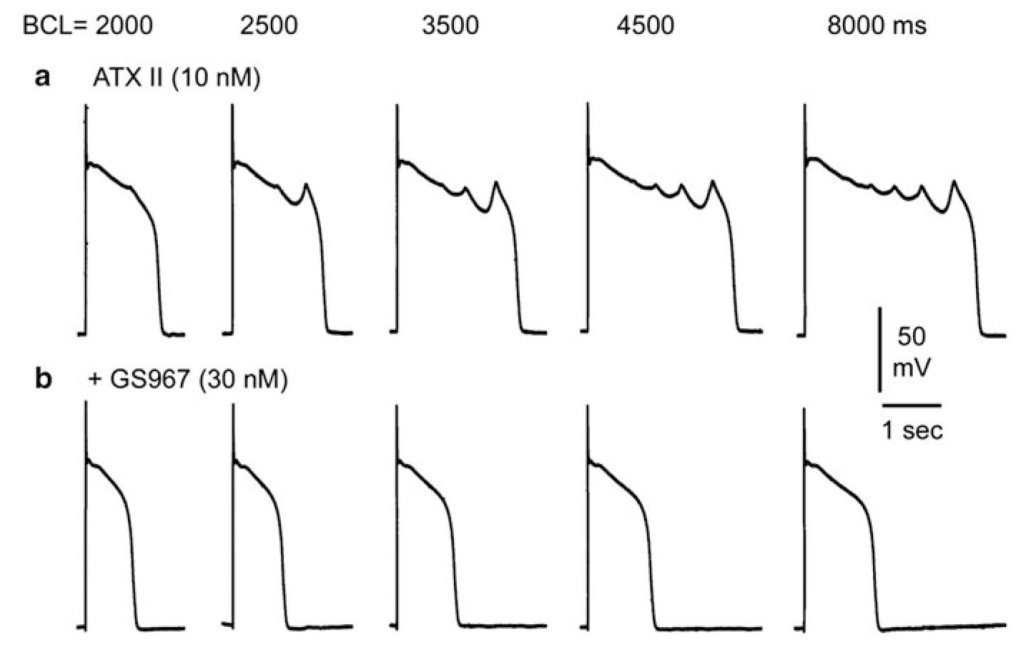

Fig. 5.

GS-458967 abolishes early afterdepolarizations (EADs) and EAD-induced triggered activity elicited by exposure to ATX-II in a canine Purkinje fiber. (a) ATX-II (10 nM) elicited EADs and EAD-induced triggered activity at basic cycle lengths (BCLs) of 2,000, 2,500, 3,500, 4,500, and 8,000 ms. GS-458967 (30 nM) abolished all EADs and triggered activity. From Sicouri et al. (2013) with permission 


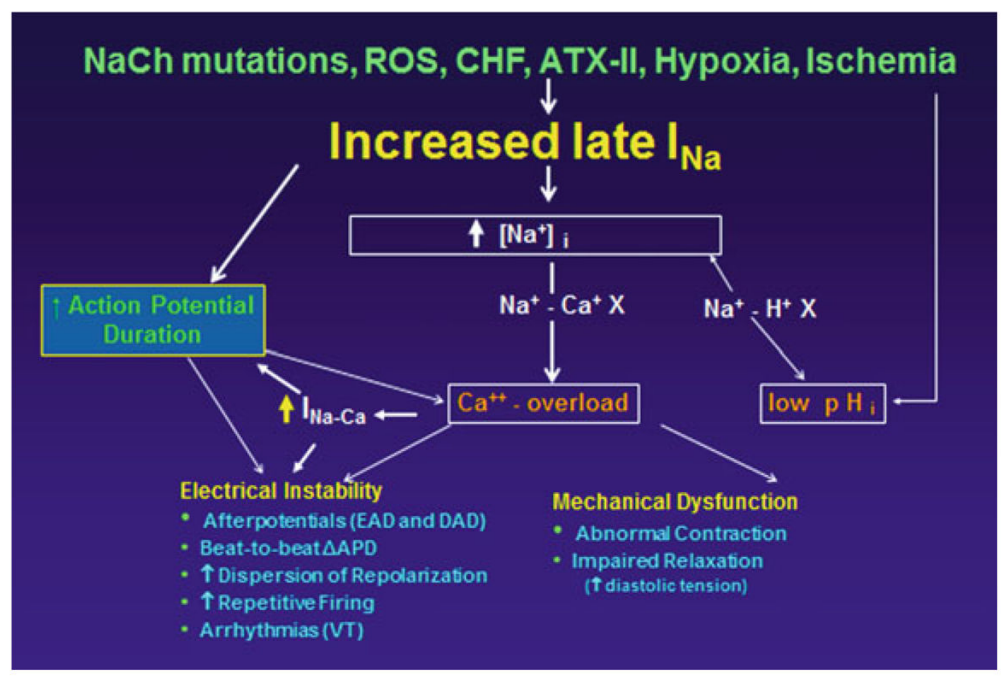

Fig. 6.

Mechanisms contributing to electrical instability and mechanical dysfunction in acquired and congenital conditions that enhance late $I_{\mathrm{Na}}$ 


\section{Table 1}

Conditions and agents that have been demonstrated to increase cardiac late $I_{\mathrm{Na}}$

\begin{tabular}{ll}
\hline Conditions/endogenous agents & Drugs and toxins \\
\hline Activation of CaMKII & Aconitine \\
\hline Activation of Fyn tyrosine kinase & ATX-II \\
\hline Activation of PKC & Batrachotoxin \\
\hline Angiotensin II & DPI 201-106 and analogs \\
\hline Carbon monoxide & KB130015 \\
\hline 2,3-Diphosphoglycerate & Ouabain (indirectly) \\
\hline Hydrogen peroxide $\left(\mathrm{H}_{2} \mathrm{O}_{2}\right)$ & Pyrethroids (e.g., tefluthrin) \\
\hline Hypoxia, ischemia & Veratridine \\
Hyperthyroxinemia & \\
\hline Lysophosphatidylcholine & \\
\hline Nitric oxide (NO) & \\
\hline Palmitoyl-L-carnitine & \\
\hline
\end{tabular}

Modified from Shryock et al. (2013), with permission 


\section{Table 2}

$\mathrm{IC}_{50}$ values for drug-induced block of peak and late $I_{\mathrm{Na}}$ as well as $I_{\mathrm{Kr}}$ by $I_{\mathrm{Na}}$ blockers

\begin{tabular}{|c|c|c|c|c|c|}
\hline \multirow[b]{2}{*}{ Drug } & \multirow[b]{2}{*}{ MW } & \multicolumn{3}{|c|}{$\mathrm{IC}_{50}$ value for tonic block $(\mu \mathrm{M})$} & \multirow[b]{2}{*}{ References } \\
\hline & & Late $I_{\mathrm{Na}}$ & Peak $I_{\mathrm{Na}}$ & hERG $\left(I_{\mathrm{Kr}}\right)$ & \\
\hline Amiodarone (acute) & 645 & $3.0,6.7$ & 178,87 & $\sim 1$ & Wu et al. (2008c), Maltsev et al. (2001) \\
\hline Flecainide & 414 & 1.4 & $10-15$ & $2.1,3.9$ & Liu et al. (2003), Heath et al. (2011) \\
\hline F15845 & 376 & $\sim 1$ & $23 \%$ at $10 \mu \mathrm{M}$ & $15 \%$ at $10 \mu \mathrm{M}$ & Vacher et al. (2009), Pignier et al. (2010) \\
\hline GS458967 & 347 & 0.2 & $>10$ & $>10$ & Sicouri et al. (2012c) \\
\hline KC12291 & 413 & $\leq 0$ & $\sim 15$ & No inhibition? & Tamareille et al. (2002), John et al. (2004) \\
\hline Lidocaine & 236 & $\sim 25$ & $\sim 300$ & No inhibition & Bean et al. (1983), Grant et al. (1989), Starmer et al. (1991) \\
\hline Mexiletine & 179 & $3-5$ & $28-253$ & No inhibition & Yatani and Akaike (1985), Sunami et al. (1993) \\
\hline Propafenone & 341 & $<1$ & $\geq 1$ & $0.4-0.8$ & $\begin{array}{l}\text { Schreibmayer and Lindner (1992), Edrich et al. (2005), } \\
\text { Witchel et al. (2004) }\end{array}$ \\
\hline Propranolol & 259 & $\sim 3$ & $22-28$ & No inhibition & Wang et al. $(2008,2010)$ \\
\hline Quinidine & 324 & 12 & 11 & $\sim 1$ & Colatsky (1982), Grant et al. (1982) \\
\hline R56865 & 413 & 0.2 & $\sim 5$ & Probable inhibition & Wilhelm et al. (1991), Verdonck et al. (1991) \\
\hline Ranolazine & 428 & 7 & 428 & $12-14$ & $\begin{array}{l}\text { Antzelevitch et al. (2004), Zygmunt et al. (2011), } \\
\text { Undrovinas et al. (2004) }\end{array}$ \\
\hline Riluzole & 234 & $2.7-3$ & $100-150$ & & Song et al. (1997), Weiss et al. (2010) \\
\hline Tetrodotoxin & 319 & 0.53 & 6.0 & No inhibition & Josephson and Sperelakis (1989), Carmeliet (1987b) \\
\hline Vernakalant & 349 & $\sim 30$ & 107 & $7-21$ & Orth et al. (2006), Fedida (2007) \\
\hline
\end{tabular}

Handb Exp Pharmacol. Author manuscript; available in PMC 2015 January 01. 